\title{
Historical framework to explain long-term coupled human and natural system feedbacks: application to a multiple-ownership forest landscape in the northern Great Lakes region, USA
}

\author{
Michelle M. Steen-Adams $^{1,2}$, Nancy Langston $^{3}$, Mark D. O. Adams $^{1}$ and David J. Mladenoff ${ }^{4}$
}

\begin{abstract}
Current and future human and forest landscape conditions are influenced by the cumulative, unfolding history of socialecological interactions. Examining past system responses, especially unintended consequences, can reveal valuable insights that promote learning and adaptation in forest policy and management. Temporal couplings are complex, however; they can be difficult to trace, characterize, and explain. We develop a framework that integrates environmental history into analysis of coupled human and natural systems (CHANS). Our study demonstrates how historical data and methods can help to explain temporal complexity of long-term CHANS feedbacks. We focus on two sources of temporal complexity: legacy effects and lagged interactions. We apply our framework to a multiple-ownership forest landscape comprising tribal and nonindustrial private forest ownerships in Wisconsin. Our framework features four elements that help investigators better understand complex systems through time: (1) a temporal axis parsed into historical periods (periodization), (2) representation of links between historical periods and system feedbacks, (3) representation of land ownership history, and (4) nested geographical scales of historical analysis. The framework can help to reveal legacy effects and lagged interactions, illuminate turning points and periods in system dynamics, and distil insights from unintended consequences that inform institutional and policy adaptation. We also assess the validity of using land ownership to represent the social component of CHANS models. When treated as a categorical variable and interpreted in historical context, land ownership can validly represent decision-making structure, culture, and knowledge system in spatially explicit social-ecological models.
\end{abstract}

Key Words: CHANS; environmental history; feedback; forest landscape; Great Lakes; historical ecology; lagged interaction; legacy; ownership; tribal; unanticipated consequence

\section{INTRODUCTION}

A useful approach to expand theoretical and applied understanding of coupled human and natural system (CHANS) feedbacks lies in explaining the temporal complexity of system interactions (Newell et al. 2005, Pickett et al. 2005, Cadanesso et al. 2006, Liu et al. 2007a,b). Humans and the landscape reciprocally affect one another through legacy, time-lag, and indirect effects, in addition to direct effects. Human history also conditions the management paradigm, practices, and in turn, CHANS feedbacks (Davidson-Hunt and Berkes 2004, Geist and Lambin 2004, Nayak 2014). Major turning points include the Industrial Revolution and 20th century globalization, when human-nature interactions increased in scope and magnitude, yet grew more indirect, difficult to trace, and complex (Liu et al. 2007b; see also environmental history analyses: McNeill 2000, Hughes 2009, Uekötter 2010). Illuminating these sources of temporal complexity is useful because this knowledge helps managers better understand the evolving dynamics of the systems they seek to manage. For instance, retrospective analysis can inform corrective policies to address unanticipated consequences that develop through lagged interactions (Millennium Ecosystem Assessment 2005), which may require a span of time to become apparent.

History governs the temporal complexity of CHANS feedbacks (Lambin et al. 2001, Pickett et al. 2005, Cadanesso et al. 2006). That is, feedback controls go beyond the mere passage and scaling of time. Historical contingency, which we define as chance events that constrain future possibilities, is difficult to represent in socialecological models, however. We need frameworks to illuminate the temporal complexity of CHANS feedbacks from an environmental historical perspective. Specifically, we need tools with which to probe system dynamics through time in relation to the particulars of the study system's time and place. There is need for expanded integrative tools that reveal legacy effects and lagged interactions, illuminate turning points, and distil insights from unintended consequences that inform adaptation. Using a multiple-ownership forest landscape in the northern Great Lakes region of the United States, we demonstrate how an environmental history framework can address these questions.

From a theoretical perspective, important CHANS questions are: How do legacy effects and lagged interactions affect feedback direction (accelerating vs. stabilizing feedback), and in turn, system resilience (Berkes and Folke 1998, Liu et al. 2007a,b)? Existing models provide useful tools to test generalizable hypotheses about temporal couplings (e.g., Gunderson and Holling 2002). These have been effectively applied to chronologies of past events of study systems (e.g., "cycles of management"; Carpenter et al. 2001). Still, we lack adequate conceptual tools to test hypotheses about feedbacks in relation to underlying historical factors (e.g., economic and political histories, culture, scientific/management paradigms) that drive behaviors. A related suite of CHANS theoretical questions pertains to explaining thresholds (i.e., transition points between system states and regimes) in relation to resilience and reversibility. Environmental historical analysis can reveal fundamental factors that influence the crossing of ecological thresholds by tracing how underlying social drivers (e.g., government policies, economic systems) developed and effects accumulated (McNeill 2000).

${ }^{1}$ Department of Environmental Studies, University of New England, ${ }^{2}$ Pacific Northwest Research Station, USDA Forest Service, ${ }^{3}$ Department of Social Sciences, Michigan Technological University, ${ }^{4}$ Department of Forest and Wildlife Ecology, University of Wisconsin-Madison 
From an applied forest sciences perspective, managers are searching for reference conditions and measurements of departure from historical conditions to inform management and restoration targets (Mladenoff and Pastor 1993, Lehmkuhl et al. 1994, Foster et al. 1998, Cissel et al. 1999, Radeloff et al. 2000, Hagmann et al. 2013). Restoration targets based on historical climate and disturbance regimes may not be viable (e.g., Ravenscroft et al. 2010). Still, knowledge of the variation in historical structures and processes might highlight restoration target areas and guide restoration of system functionality (Bolliger et al. 2004). An environmental history framework can provide valuable ecological, climatic, and social-politicaleconomic context to interpret reference conditions and change and to evaluate proposed restoration targets (Langston 1995, Donahue 2000, Foster et al. 2005, Langston 2006).

We build on our environmental history study of a multipleownership, transitional forest landscape in the northern Great Lakes region (Steen-Adams et al. 2007, 2010, 2011) to examine how historical contingency conditions CHANS feedbacks. Past research has documented the landscape history of sites historically dominated by eastern white pine (Pinus strobus). We conducted a transition analysis to quantify the magnitude and rate of landscape change over three transition intervals (i.e., 18601930, 1930-1950, and 1950-1990) and applied multinomial regression to assess the relative influence of biophysical factors (soil texture, elevation, spatial location) and social-political ownership history (Ojibwe Indian reservation vs. nonindustrial private forest [NIPF]).

Two objectives guide our study. Our first objective was to develop and apply a framework to demonstrate how historical data and methods can illuminate temporal complexity of long-term CHANS feedbacks. We were interested specifically in the following applications: reveal legacy effects and lagged interactions, illuminate turning points and periods in system dynamics, and distil insights from unintended consequences that inform institutional and policy adaptation. Our second objective was to assess the validity of using land ownership as a proxy variable to represent the social component of CHANS models.

\section{Temporal complexity}

Temporal complexity refers to system relationships that extend past current, direct connections (Pickett et al. 2005, Cadanesso et al. 2006, Liu et al. 2007b). Legacy effects and lagged interactions are two main dimensions of temporal complexity. Investigators have demonstrated legacy effects of past anthropogenic alterations such as land use on landscape pattern and processes (e.g., Motzkin et al. 1996, Goodale and Aber 2001). In addition, past social-political conditions have introduced persisting effects on forest management (Geist and Lambin 2004, Ostrom and Nagendra 2006). Second, lagged interactions influence system feedbacks (Parson 2003, Liu et al. 2007b:643). Lagged interactions refer to those characterized by a time interval between social-ecological interactions and their effects. Decades or centuries might pass before biophysical or social effects develop, with a longer time-lag for people to perceive effects. An even longer feedback period might be required for system agents to formulate a response.

A related body of CHANS literature examines feedback loops in the context of human history (Geist and Lambin 2004, Steffen et al. 2004). The post-Industrial Revolution (Anthropocene), when the scope, magnitude, and rate of human impacts on the environment exceeded that of past periods (McNeill 2000, Hughes 2009, Uekötter 2010), is primarily examined (e.g., Steffen et al. 2004, Liu et al. 2007b). The present period of the Anthropocene might obscure the relevance of historical analysis. However, historical analysis can illuminate current conditions of social-ecological systems in several ways (Newell et al. 2005), including catalyzing events ("trigger events") that introduce new system periods and management shifts (Burton et al. 2010), alternative pathways ("path dependence"; Lambin and Meyfroidt 2010), and environmental narratives (Hessburg and Agee 2003).

Unanticipated consequences (system surprises) are a second theme of literature pertaining to CHANS temporal complexity. These outcomes often arise due to indirect feedbacks of slow variables, i.e., factors that develop over time scales that can greatly exceed human lifetimes (Carpenter and Turner 2000, Newell and Wasson 2002, Liu et al. 2007b). Insights relevant to adaptation and learning, including adaptive management, are revealed: retrospective analysis presents learning opportunities by tracing how unexpected outcomes of policies, knowledge systems, or other factors (e.g., sustained-yield forestry paradigm, conventional resource management, various flood mitigation policies) have developed over time.

\section{Illuminating coupled human and natural system feedbacks through an environmental historical perspective}

Feedbacks are defined as reciprocal interactions between humans and natural patterns and processes and can involve reciprocal flows of materials, organisms, energy, and information. Feedbacks structure system dynamics and bear implications for environmental sustainability and human wellbeing (Millennium Ecosystem Assessment 2005, Liu et al. 2007b). We consider both accelerating (positive) and stabilizing (negative) feedbacks. In an accelerating feedback, social change triggers an adverse system state change in the landscape component (or vice versa), the effects of which loop back to affect the social component; system degradation amplifies over time (e.g., Steffen et al. 2004, Carpenter et al. 2007). In a stabilizing feedback, humans respond adaptively to ecological degradation, stabilizing the system.

Environmental history provides a methodology with which to examine long-term feedbacks. Environmental historians typically explore three categories of change: biophysical change (ecosystem components), socioeconomic change (demographics, economics), and intellectual change (culture, religion, ethics; Worster 1988). The key insight of environmental history is that change in one system component can alter other component characteristics (e.g., landscape structure), leading to unintended consequences that can generate complex feedbacks. For example, policies and programs designed to deliver desired ecological outcomes have sometimes instead led to ecosystem degradation and in turn maladaptive management practices (Pyne 1982, Langston 1995, Geist and Lambin 2004, Pyne 2010).

Revealing how complex feedbacks develop through time can inform policy adaptation. For example, as Hirt (1994) showed for the U.S. Department of Agriculture Forest Service, increased funding for resource management increased forest stand 
productivity in the short term. A complex feedback resulted when politicians saw the increased forest yields and assumed that they were the natural, unfluctuating output of a managed forest. They became framed as minimum yield quotas, and politicians made funding for forestry operations dependent on elevated yields (Hirt 1994). Agency administrators came to depend on that funding, leading to increased yield projections to grow agency allocations, which in turn encouraged politicians to increase their expectations of future forests. This led to a "ratcheting up" of timber outputs, reducing forest biodiversity and constraining management options.

\section{Institutional and knowledge system influences on feedbacks}

Institutions, defined as the "humanly devised constraints that structure human interaction" (Berkes and Folke 1998, also Ostrom 2005), influence feedbacks. This multiple-scale set of rules, which may be formal (policies, laws) or informal (norms of conduct such as common property access), condition how system actors develop ecological knowledge and recalibrate management practices.

Knowledge systems also influence human-nature interactions. Traditional ecological knowledge (TEK) refers to the "traditional body of knowledge and beliefs, handed down through the generations through cultural transmission, about the relationship of living beings (including humans) with one another and their environment" (Berkes et al. 1995:282). "Traditional" connotes the historic and cultural continuity of knowledge development and refinement. TEK develops through time, in relation to human history, and recognizes the complexity of ecological, political, and cultural factors that shape environmental management (Berkes et al. 2000, Berkes and Jolly 2001, Davidson-Hunt and Berkes 2003, Garibaldi and Turner 2004, Charnley et al. 2007). Local ecological knowledge (LEK) refers to knowledge, practices, and beliefs that are gained through extensive interaction with local ecosystems (Charnley et al. 2007). TEK and LEK can be contrasted with "conventional resource management", which is based on Newtonian science and government expertise, and can be disconnected from local conditions (Berkes and Folke 1998). Whether TEK/LEK or a conventional resource management approach directs management practices can influence feedback direction (stabilizing vs. accelerating feedback).

\section{Land ownership as a proxy for social complexity}

Although human groups are often represented as homogeneous entities in system models, people have numerous, often conflicting, motivations, even within the smallest group (Beard et al. 2003). No model can include all these varied motives, yet it is important to incorporate at least some of the social complexity.

Investigators have employed ownership class as a variable to examine human influence on forest landscape pattern (Mladenoff et al. 1993, Turner et al. 1996, Spies et al. 2007). Different ownership classes may implement varying management practices (e.g., Fischer and Charnley 2012), in turn influencing landscape structure.

Using land ownership class to categorize humans into groups clearly ignores much social variation, however, and is an imperfect proxy for all of the complexities of human history. Our interest is in human history as it relates to forest landscape decisionmaking. We examine whether using land ownership class to categorize human groups offers a useful proxy to represent social complexity (i.e., variation in decision-making structure, culture, and knowledge system) without overwhelming the model.

\section{METHODS}

\section{Environmental history-coupled human and natural system framework}

Our framework helps investigators of multiple-ownership systems trace, characterize, and explain the influence of long-term feedbacks on current and future human and forest landscape conditions (Fig. 1). The framework comprises four main elements: landscape, ownership social component, ownership environmental history periods, and broad-scale (regional/national/global) environmental history periods. Feedbacks link framework elements.

Fig. 1. Environmental history-coupled human and natural systems (CHANS) framework to examine the influence of longterm CHANS feedbacks on current conditions of multipleownership forest landscapes. The natural and social landscape components of the system can be examined through time, represented as consecutive landscape states (state $t_{0}, \ldots t_{\mathrm{n}}$ ). The framework comprises four main elements: landscape (level 1), ownership social component (level 2), ownership environmental history periods (level 3), and broad-scale (regional/national/ global) environmental history periods (level 4). Feedbacks, i.e., reciprocal flows of materials, organisms, energy, and information, link the framework elements.

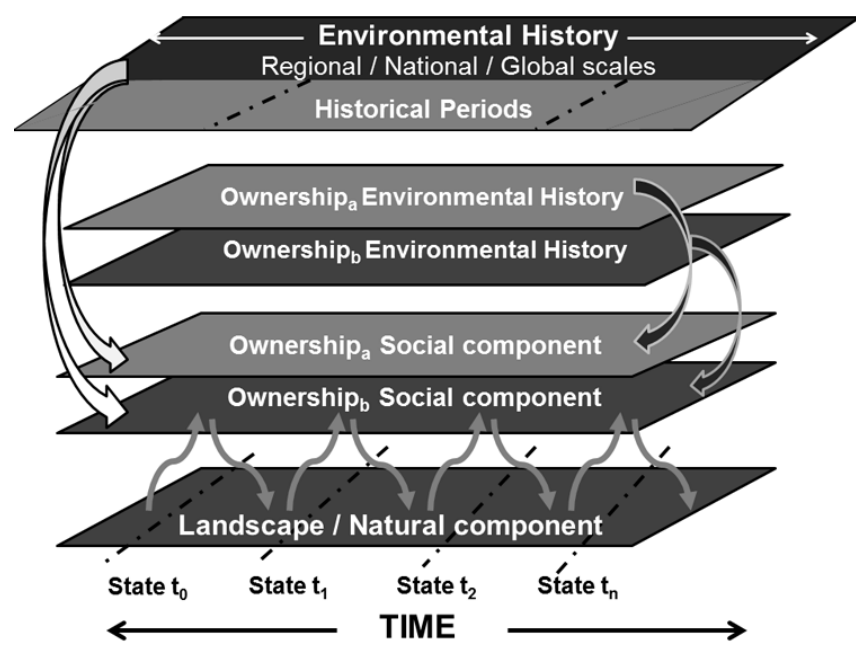

Along the temporal axis, we follow the norms of professional historians by parsing the continuum of time into definable, coherent periods, a process called periodization (Green 1995, Bentley 1996, Cronon 2004). Periodization is the process of "dividing the seamless continuum of past time into a sequence of discrete periods that perform roughly the same storytelling function as the chapters of a book" (Cronon 2004). The utility to CHANS investigators lies in provision of a temporal framework that structures patterns of continuity and change. Historical periods signal transition points that demarcate significant shifts in predominant worldview, system of governance, and economy. 
Broad historical forces condition management objectives of system actors and thus landscape change.

The landscape forms the base layer. Landscape structure and processes change through time; for analysis, we characterize selected states $\left(t_{0} \ldots\right)$, which represent snapshot conditions of specified dates. The second layer is the social component. This component changes through time in a material sense, e.g., population. In a multiple-ownership landscape, the social component is represented as multiple model layers: these layers represent heterogeneity in ownership, as well as relevant management practice. Management variation may generate dissimilar forest responses. Feedbacks, represented as arrows, link the human and landscape components.

The third and fourth levels represent two related types of environmental historical influences on feedbacks and system conditions. Some historical factors pertain specifically to a single ownership. We represent these forces in the third level. Historical factors include political and economic systems, culture (values, traditional practices), and scientific and management paradigms. The fourth level represents historical factors beyond those of the ownership history that influence CHANS dynamics. This level operates at multiple geographic scales (local, regional, national, global) and may span multiple ownerships.

\section{Study area}

Our case study is situated on a 79,770 ha $(197,115$ acre $)$ subsection of the Lake Superior clay plain (approximately $46^{\circ} 30^{\prime} \mathrm{N},-90^{\circ}$ 75'; Fig. 2). Two ownerships (Indian reservation and NIPF) adjoin one another on a landscape that has relatively uniform biophysical characteristics. The entire study area lies within a single ecoregion subsection unit: Ashland Lake-Modified Till Plain land type association (WDNR 1999, 2012).

Fig. 2. Location of the northern Great Lakes-Wisconsin study area and land ownerships of the Bad River Indian Reservation and nonindustrial private forest (NIPF).

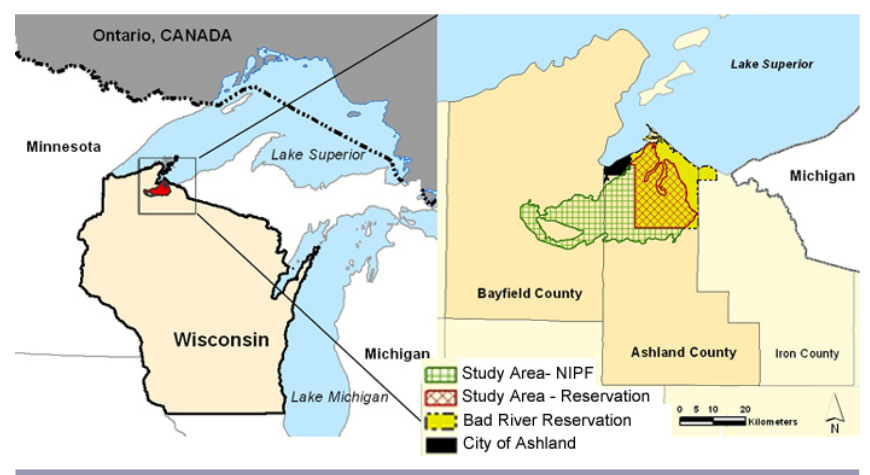

The entire study area lies within the so-called northern Great Lakes "cutover" (Gough 1997). Between approximately 1870 and 1920, intensive railroad logging, often combined with high-fuelload fire, brought about catastrophic ecological disturbance (Stearns 1988, Williams 1989, Whitney 1994). In the early 20th century, poverty and land abandonment prompted vigorous debate over the region's future, i.e., whether to promote reforestation or agriculture (Carstensen 1958). Different groups responded dissimilarly to deforestation, which led to varying landscape feedbacks.
Forest landscape component

Forest communities of the Lake Superior clay plain (Province 212Ja), a sub-section of the Laurentian Mixed Forest (USFS Province 212, http://www.fs.fed.us/land/pubs/ecoregions/ch14.

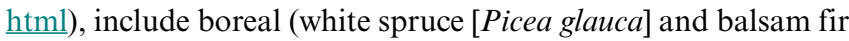
[Abies balsamea]; following Curtis 1959), white pine, and trembling aspen (Populus tremuloides)-white birch (Betula papyrifera; WDNR 2012). The clay plain lies within a transitional zone between mixed conifer-hardwood forest to the south and boreal forest to the north, generating elements of both forest types. The climate is continental, with cold winters, deep snow, mild summers, and high humidity; the soil is lacustrine clay, interspersed with sand lenses; and the landform is lake plain cut by deep ravines: Collectively, these factors influence the forest landscape pattern.

Using a GIS, we characterized landscape composition and structure (scale: 65 ha [160 acre] cell size), focusing on the white pine-dominant component only, at four states (1860, 1930, 1950, 1990). Study sites $(N=95)$ were identified via a stratified random sample of historic (1860) white pine-dominant sites, based on relative importance value (RIV). We assessed dominant land cover to quantify forest landscape change for 1860-1930, 1930 1950, and 1950-1990. Land-cover data are derived from historic forest inventories (U.S. Public Land Survey for 1860, Wisconsin Land Economic Inventory for 1930) and remotely sensed imagery (aerial photography for 1950, multi-temporal satellite imagery for 1990). Data source details (RIV quantification) and methods to inter-relate the diverse data sets (classification scheme cross-walk) are described elsewhere (Steen-Adams et al. 2011).

\section{Human component: ownership and environmental history}

Ownership

We analyzed the complex ownership pattern of the Lake Superior clay plain by developing two main classes: reservation and NIPF (Fig. 2). Land ownership data, in combination with historical analysis, revealed that although some landowner class diversity exists within each ownership zone, two distinct modes of humanlandscape interactions developed. We modeled the influence of land ownership on landscape pattern (Steen-Adams 2005, SteenAdams et al. 2011, Jin et al. 2013, Fu et al. 2013). We acknowledge that landowners developed management decisions individually, not monolithically, as the coarse category, "ownership class", might imply. We grapple with balancing representation of landowner diversity within each ownership zone while maintaining adequate parsimony by developing a more finegrained environmental history analysis elsewhere (e.g., SteenAdams 2005, Steen-Adams et al. 2010).

NIPF ownership applies to one landscape zone. A mixed economy of small-scale agriculture, forestry, government, and off-farm employment characterizes this system during the study period. This is a coherent unit, despite ownership fragmentation, because of the predominant social history and culture of multigenerational residents descended from ancestors who shared similar backgrounds (primarily first-generation Scandinavian, German, and Slavic immigrants). This social situation shaped values and practical knowledge, access to capital, and community social networks (Gough 1997). Rural zoning history justifies analysis as a single ownership zone. Following 1929 state legislation that enabled county rural zoning (Carstensen 1958), and 1934 local adoption of rural zoning ordinances, the study 
area primarily lies within a single rural zone category ("unrestricted", not "forestry"), in correspondence with a uniform soil type (primarily Ontonagon Bergland; ACLUPC 1941, U.S. Department of Agriculture 1961). However, landowners operated autonomously and independently in this highly fragmented landscape. This analytical approach carries the limitation of obscuring the distinct histories that lie within the NIPF zone.

Reservation ownership refers to the land historically designated as the Bad River Indian Reservation by the 1854 U.S. Treaty with the Chippewa and which intersects with the clay plain $(31,810$ ha [78,604 acres] of the 50,590 ha [125,000 acre] reservation). During the 20th century, the overlapping processes of land allotment (following the 1887 General Allotment Act [Dawes Act]), land alienation, and heirship fractionation generated a complex, checkerboard ownership pattern. By 2001, ownership composition consisted of tribal trust (18\%), allotted (30\%), tribal fee $(5 \%)$, and alienated lands (47\%; BRNRD 2001). We treat reservation ownership as a single, broad category to examine social-ecological feedbacks for several reasons: (1) the sustained, pervasive Bureau of Indian Affairs (BIA) influence on forest management, e.g., overseeing allottee harvest contracts $(97 \%$ of the reservation was historically allotted; BRNRD 2001) and forest inventories (e.g., Bad River Continuous Forest Inventory of 1962, unpublished data); (2) the large proportion of alienated parcels held by timber companies that implemented forestry practices similar to those of the BIA (Godfrey 1996, Steen-Adams et al. 2007); and (3) practical analytical challenges posed by ownership pattern changes (1905-1986).

Reservation ownership is a proxy for decisions made by the Bureau of Indian Affairs for the reservation forests of the Bad River Ojibwe. From the beginning of reservation forest management history through the 1980s, the BIA (prior to 1947, Indian Agency) controlled decision-making, largely ignoring input from the Bad River Ojibwe community, e.g., Tribal Council (Godfrey 1996, Loew 1998, BRNRD 2001). As we argue elsewhere (Steen-Adams et al. 2010), the Agency vision of the forest as an economic resource prevailed over tribal cultural values, contributing to unanticipated, adverse consequences for the tribal community. In general, Agency practices were intended to address significant economic needs that the tribe confronted. In view of dissimilar forest management visions between the BIA and tribe, reservation ownership should be interpreted with caution. Its social and political meaning changes over time, and the historical periods that we chose include this complexity.

Environmental history of the Bad River Reservationnonindustrial private forest landscape in the northern Great Lakes region

Ojibwe ancestors of the Bad River Band settled the southern shore of Lake Superior, drawn in part by the productive beds of wild rice (Zizania spp.) in the Kakagon Sloughs (Danziger 1979, Morrison 2002, Loew 2013). The Ojibwe developed a woodland culture and subsistence economy based on seasonal travel to gather, hunt, and fish from the region's forests, wetlands, and waters (Rasmussen 1998, Loew 2013). Tribal members collected wild rice from the Kakagon Sloughs, harvested construction and household materials (e.g., white birch bark), collected berries and hunted game from the boreal forests, and fished and trapped fur- bearing mammals from the Lake Superior coastline, inland lakes, and streams (Fig. 3).

Europeans arrived in the region as explorers, missionaries, and fur traders in the 1600s (White 1991). Euro-American immigration increased in the mid-1800s, when word of rich ore deposits drew waves of miners. Miners were followed by loggers intent on harvesting white pine and other timber types. Agricultural settlement followed logging, with farm numbers peaking between 1900 and 1920 (Vogeler 1983). Cutover land typically shifted among three ownership types: lumber companies abandoned cutover land, which land companies then purchased and sold to settlers. Promotional materials, introduced by real estate companies, university agronomists, and local boosters, drew settlers from Europe and the eastern United States. These settlers developed an economy based on mixed husbandry agriculture, often paired with seasonal winter labor in lumbering and mining camps.

To facilitate mining, the United States secured land cessions from the tribes, which then paved the way for logging (Satz 1991). The treaties of $1836,1837,1842$, and 1854 brought about cessions from the Great Lakes Ojibwe tribes of their homelands, comprising all of the Michigan Upper Peninsula, approximately one-third of Wisconsin, and approximately one-fifth of Minnesota. However, the tribes were careful to retain usufruct rights on ceded territories, particularly rights of hunting, fishing, and gathering. Land loss, disease, violence, and poverty of the treaty era brought about catastrophic cultural and economic upheaval for the Ojibwe (Rasmussen 1998, 2003, Loew 2013).

We use three periods to structure analysis of human-landscape feedbacks through time, following precedent historical ecological frameworks (Steen-Adams et al. 2011, see also Carpenter et al. 2007). The body of historical policies and processes, which varied among ownership zones, influenced the forest landscape management decisions of Indian Agency officials, foresters, and owners. We assess whether variation in historical factors propagated differing feedbacks.

\section{Frontier/Euro-American settlement/imposed assimilation (1860-1930)}

Feedbacks of 1860-1930 interval were influenced by multiple processes, some of which occurred only on the reservation or the NIPF area, and some that spanned both zones. At Bad River, as across Indian reservations, the U.S. policy of acculturation and assimilation was imposed on tribes (Loew 2013). In correspondence with this policy, the La Pointe Indian Agency, which administered multiple Great Lakes reservations, attempted to transform the Ojibwe woodland culture to one consistent with dominant Euro-American culture. The General Allotment Act of 1887 (Dawes Act) divided communally held tribal land into individual allotments, eventually attenuating traditional ties to the land. This legislation, in combination with the Burke Act of 1906 , led to the loss of nearly two-thirds of the total U.S. Indian land base (36.4 million ha [90 million acres]; Indian Land Tenure Foundation, https://www.iltf.org/). On the adjoining NIPF region, immigration and frontier settlement was a key driver. Across the Great Lakes region, including both ownerships, national objectives for regional development promoted harvest of primary forest pines (Cronon 1991). 
Fig. 3. Elements of traditional Ojibwe interactions with the northern Great Lakes environment. (A) "Joe Stoddard of the Chippewa Tribe harvests wild rice on the Bad River Indian Reservation." Photograph by Joe Vachon, 1941. Image ID: WHi 34567. (B) "An Ojibwa woman, Francis Mike, harvesting wild rice in a boat on Totogatic Lake, Wisconsin.” Photograph by Fred Morgan Photography, no date. Image ID: WHi 24509. (C) "Removing birch bark." (D) "Making container from birch bark." Credit: F. Densmore, 1928. Use of plants by Chippewa Indians, Government Printing Office, Washington, D.C., USA. (A and B) Reprinted with permission of the Wisconsin Historical Society, Madison, Wisconsin, USA. (C and D) Courtesy of the Clarke Historical Library, Mount Pleasant, Michigan, USA.

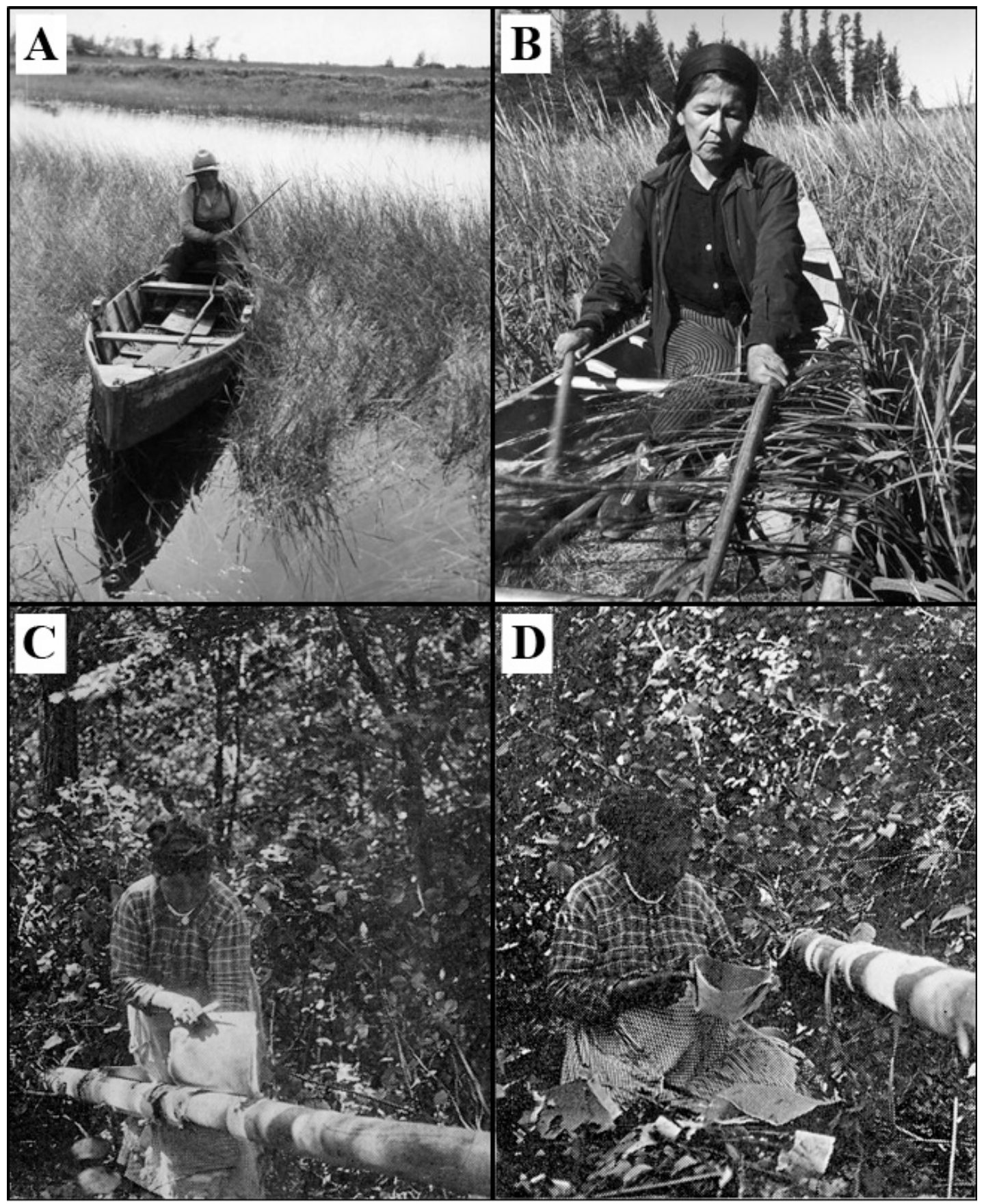


Table 1. Land ownership composition (percentage) of the Bad River Indian Reservation zone of the Lake Superior clay plain study area at four times states: 1905, 1917, 1958, and 1986. The Lake Superior clay plain study area comprises $62.9 \%$ of the reservation (31,810 of 50,590 ha $[78,604$ of 125,000 acres]).

\begin{tabular}{lcccc}
\hline \hline Ownership class & 1905 & 1917 & 1958 & 1986 \\
\hline Corporate forest industry & 1.0 & 2.5 & 17.0 & 29.9 \\
Corporate nonforest industry & 1.9 & 1.2 & 0.6 & 1.2 \\
Individual & 91.4 & 92.3 & 17.9 & 24.5 \\
Federal (e.g., Tribal trust) & - & - & 14.1 & 41.8 \\
State/county/local government & - & 1.4 & 0.1 & 2.3 \\
Other/no data & - & 2.6 & - & - \\
Vacant & 5.7 & - & 100.0 & 100.0 \\
Total & 100.0 & 100.0 & & 0.3 \\
\hline
\end{tabular}

\section{Modernization (1930-1950)}

At the beginning of the modernization period, national economic depression (U.S. Great Depression of 1929-1933) influenced forest landscape decisions. Regional influences on management decisions were progressive-era-inspired statewide forest and landuse planning (e.g., following the Clarke-McNary Act of 1924), rural zoning (Carstensen 1958), and attempted improvement of past failed Indian policies (e.g., the Indian Reorganization Act of 1934). The legislation had the potential to stabilize maladaptive feedbacks that had developed between communities and the forest landscape.

\section{Industrial/mixed economy period (1950-1990)}

The industrial/mixed economy period spans multiple, dissimilar human history intervals. During the post-World War II baby boom period (1946-1964), economic growth and industrial production predominated. Shifting values of the environmental era (mid-1960s to 1970s) promoted rural migration and recreation. In Great Lakes Indian Country, the American Indian Movement of the 1970s encouraged self-identification with native culture. More important, increased economic opportunity enabled tribal members to return to reservations (Johnson 2009; P. Loew, University of Wisconsin-Madison and member of Bad River Band of Lake Superior Ojibwe, personal communication). This social transition potentially set the stage for management improvement.

\section{Management context}

The persisting aftermath of the "lumberman's assault" (Williams 1989, Whitney 1994) on the region's forests influences current forest management and restoration objectives. Managers and stakeholders have developed workshops, partnerships, and projects spanning the NIPF and reservation zones to restore forest biodiversity and structure. White pine, a historic dominant conifer and regionally iconic species, is a focal restoration species in the study area (Clark and Niese 2000, Troxell et al. 2000) and region (Stearns 1988, Mladenoff and Pastor 1993). Conveners of a local restoration workshop observed, "[in] the past... no politicians, or civic groups...save[d] even a mere thirty or forty thousand acres of the pristine forest.... And in those ...places where I chance find a few large yellow birch, hemlock, and white pines standing together, I have come to realize there is yet hope for the forests and for our heirs -in the future... The restoration of a large tract of forests to an old-growth condition could someday begin right here in Wisconsin....[I]t can and should be done" (van Stappen 1998).
Watershed restoration is a related landscape-scale, multipleownership endeavor (Trout Unlimited-Wisconsin and Friends of White River 2004). The tribe, neighboring NIPF landowners, and nongovernment organizations (e.g., The Nature Conservancy), have developed partnerships to protect the Kakagon/Bad River Sloughs, which are habitat to culturally important wild rice and other ecological elements (Spotts 1994). Soil texture, landform, and topography increase the resource management challenge. The area's clay soils and steep $\mathrm{V}$-shaped ravines are conducive to erosion, which forestry practices (e.g., aspen clearcuts) and agricultural land use have accelerated (Fitzpatrick et al. 1999). Sediments accumulate in the watershed delta (WDNR 2007).

\section{Data sources}

We derived environmental history data from government reports, correspondence, and newspaper articles of the National Archives (Record Group 75, BIA), the University of Wisconsin-Madison archives (University of Wisconsin Agricultural Experiment Station reports), the Wisconsin State Historical Society (e.g., Lake Superior Farmer), and the Ashland, Wisconsin, BIA field office. Second, we conducted oral history interviews in 2002-2004 $(N=$ 40; 11 with participants from the Indian reservation, 29 with participants from the NIPF zone).

Population data were compiled from records of the U.S. Census Bureau (Census of Population and Housing, http://www.census. gov/prod/www/decennial.html). We analyzed records for the period 1890-1990 at the county scale. We limited our analysis to the primary county of the study area, Ashland County, Wisconsin ( $70.2 \%$ of study area). To relate this social variable to the study area's main ownership classes, we focused on Indian and nonIndian population groups. We limit our analysis to rural population data, not total population data. Rural population excludes urban population (e.g., city of Ashland, Wisconsin), which lies outside of the study area boundary and is unlikely to influence rural land-use decisions. Reservation population was cross-checked with published sources (Sandefur et al. 2000).

Land ownership data were derived from historical plat maps (1905-1906, 1915-1917, 1958-1960, and 1986-1987) that span the study period (1860-1990). Parcel boundaries were digitized and analyzed in the project GIS (Steen-Adams 2005).

\section{RESULTS}

We applied our framework (Fig. 1) to the Lake Superior clay plain (Fig. 4) to gain insight into current forest landscape management and restoration options. Feedbacks were examined in relation to 
ownership, i.e., Indian reservation or NIPF (framework levels 1 and 2), and environmental history (framework levels 3 and 4), which spans three periods: frontier/Euro-American settlement/ imposed assimilation (1860-1930), modernization (1930-1950), and industrial/mixed economy (1950-1990).

Fig. 4. Application of integrative environmental historycoupled human and natural systems framework to the humanforest landscape system on the Lake Superior clay plain, Wisconsin.

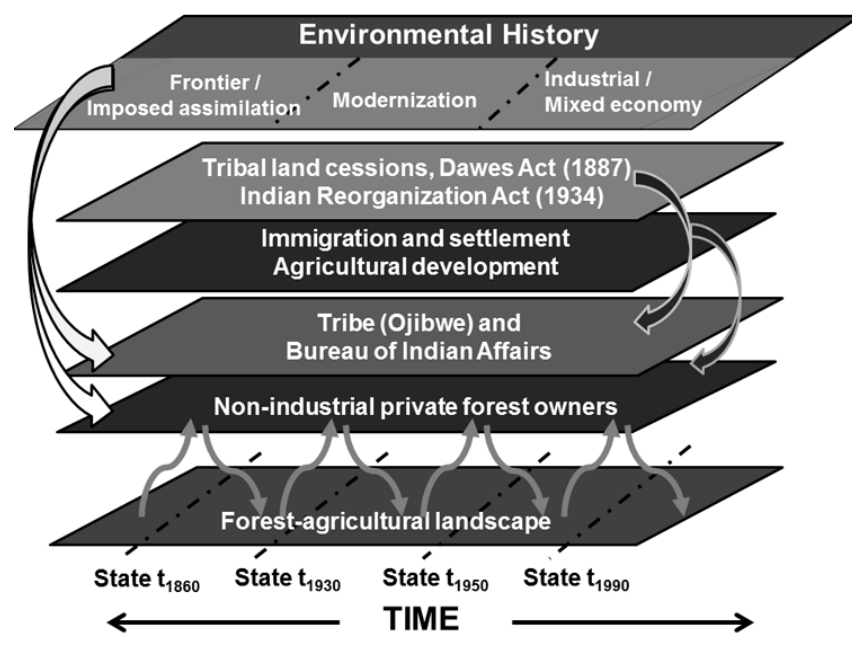

Legacy and lagged effects on the historic white pine component and restoration options

Logging practices of the 1860-1930 period introduced persisting alteration to forest structure and reforestation processes. During this time interval, lumbermen harvested 1.5 billion board-feet of white pine and other species from the 50,607 ha [125,000 acre] reservation (Fig. 5A). The intensive harvest removed white pine as a forest dominant and sharply reduced seed sources. Catastrophic slash fires (1890-1893 and 1908-1910) damaged the soil substrate, compounding the harvest legacy effect (Godfrey 1996, BRNRD 2001). The interaction of reduced seed sources, poor soil conditions, and altered disturbance regime continued to inhibit pine reforestation decades later (Steen-Adams et al. 2007).

Still, through the 1930s, Agency managers had options to promote white pine restoration. Policies to retain seed trees (1900-1909), the persistence of refugia pines located on sites inaccessible to harvest, and the program to control the white pine blister rust pathogen (Cronotarium ribocola) combined to present a window of opportunity for restoration (Fig. 5B; Steen-Adams et al. 2007).

Harvest of the old-growth pines, in combination with economic conditions, led to loss of the tribal land base that played out over the 20th century. Tribal poverty drove many tribal members to sell land (Loomer 1954), as occurred across U.S. Indian reservations (Indian Land Tenure Foundation, https://www.iltf. org/). Forest products corporations steadily increased their land holdings, especially after 1950 (Table 1). As nontribal ownerships increased, fragmentation of tribal land increased (1917-19581986; Loomer 1954, Steen-Adams 2005; Fig. 6).
Besides legacy effects of original forest harvest of white pine restoration, lag effects of land ownership change also diminished restoration options. Lag effects played out in two ways. First, land fragmentation diminished the cost-effectiveness of the white pine blister rust control program. Forest parcel fragmentation, combined with decreasing labor resources and funding (curtailment of Indian Emergency Conservation Work Program), eventually shut down systematic pathogen control (Steen-Adams et al. 2007). In response, foresters shifted from a program that included some (albeit limited) white pine management to one that focused nearly exclusively on even-aged management (aspenpaper birch landscape proportions of $92.5 \%$ in 1930 and $72.6 \%$ in 1950), to the exclusion of white pine (Fig. 7A). Second, expansion of forest industry ownership promoted pulpwood prescriptions. Widespread clearcuts reduced seed sources, compacted the low-lying, moist, clay soils, and possibly altered canopy-understory sunlight dynamics associated with the short rotation interval. In sum, interacting social and biophysical factors further constrained restoration options.

\section{Framework application to long-term feedbacks in a multiple- ownership landscape}

We examined whether differing feedbacks developed in relation to ownership, driven by different responses to deforestation. In a maladaptive, accelerating feedback, system actors (managers, land owners) make decisions that fit poorly with social-ecological conditions; system responses lead to unintended consequences that constrain management options, thereby amplifying maladaptive practices. In an adaptive, stabilizing feedback, actors observe social-ecological responses to management interventions and adjust their practices accordingly. Where needed, corrective management responses improve upon past deleterious practices, thereby stabilizing the system.

Human responses to ecological conditions are situated within the environmental historical context. These interactions influence whether actors adapt behaviors to system social-ecological structure and process, and thus, whether a destabilizing or stabilizing feedback predominates, as demonstrated by a comparison between ownerships and through time.

\section{Long-term feedbacks on the Bad River Indian reservation}

Over the 1860-1990 time span, maladaptive, destabilizing CHANS feedbacks developed, leading to adverse effects on the forest landscape and the tribal community. Beginning in the 1980s, however, system deterioration led to a regime change, which began to increase social-ecological system resilience.

\section{Frontier/Euro-American settlement/imposed assimilation (1860-1930)}

The policy of Indian assimilation through land allotment, forest harvest, and attempted farmstead development set the context for Indian Agency forest management decisions. The Agency perceived the old-growth pines as a source of capital to finance the development of Indian farmsteads, despite the maladaptation to Ojibwe woodland culture (Loew 1998, Steen-Adams et al. 2010).

The old-growth white pine dominant stands were completely deforested through Agency-organized timber sales (1894-1922), combined with high fuel load fires (1930 landscape proportion at 65-ha scale of analysis: 0\%; Fig. 7A). Aspen-paper birch reforested the vast proportion of the cutover sites (1930 landscape 
Fig. 5. Legacies of historic white pine forest harvest and management. (A) Timber harvest at the Bad River Indian Reservation by J. S. Stearns Lumber Company employees. Words at photograph bottom state that the sled carries $263 \operatorname{logs}$, which would yield 18,910 board-feet of lumber. Source: Steen-Adams et al. (2010); reprinted with permission of American Indian Culture and Research Journal; from the archives of the Washburn Area Historical Society Archives, Washburn, Wisconsin, USA. Probable photo period: 1895-1915. (B) Map of white pine blister rust control, Bad River Indian Reservation, Bureau of Indian Affairs (BIA), December 1935. Map highlights sites where the BIA directed field crews, including Indian Emergency Conservation Work program crews, to implement gooseberry (Ribes) eradication treatments. Map indicates location of remnant white pines. Source: Steen-Adams et al. (2007); reprinted with permission of Environmental History; image source: Earl E. Nielson, 1935, Addendum to blister rust spotters report, Bureau of Indian Affairs, Ashland, Wisconsin, USA field office.

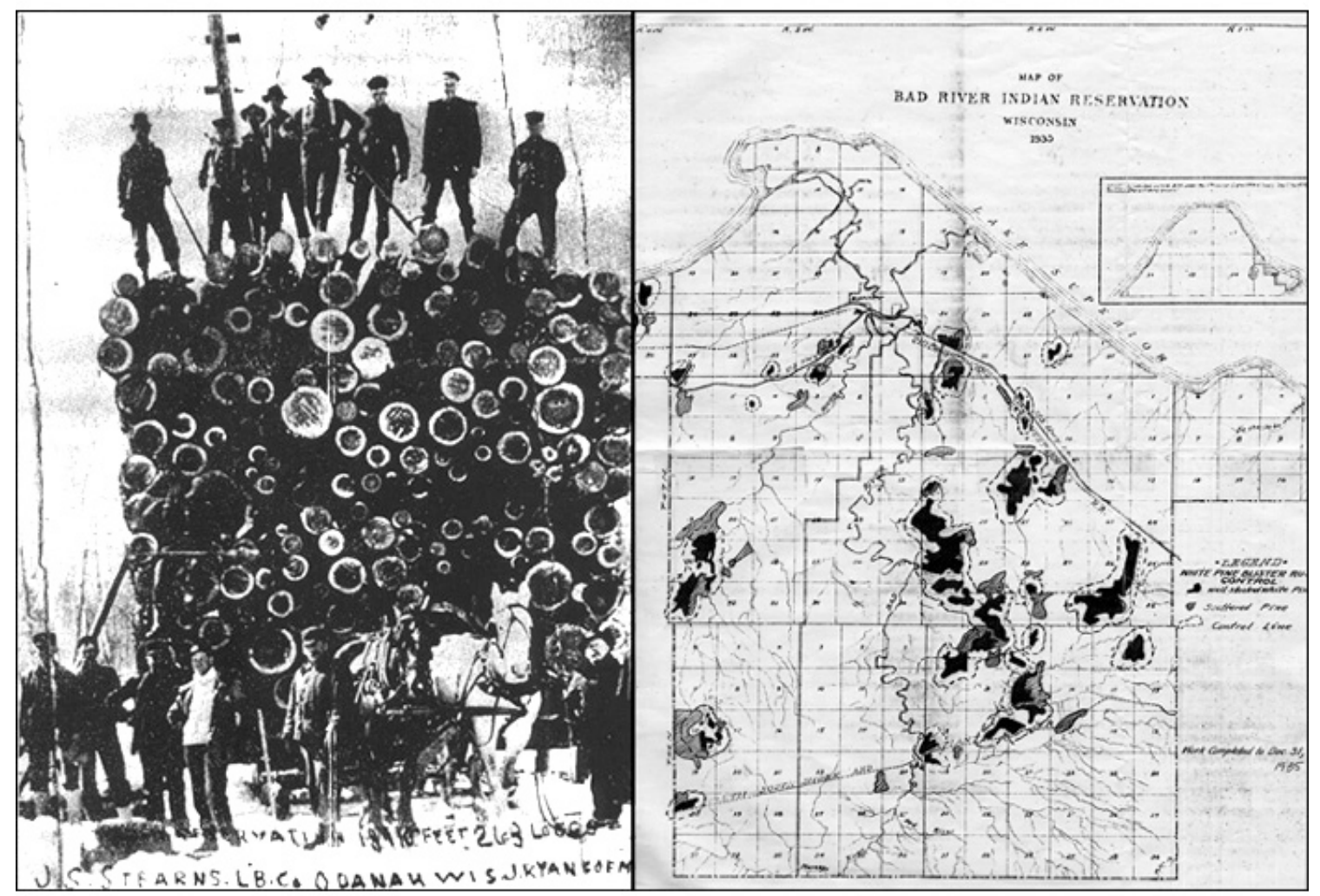

proportion: $92.5 \%$ ). Though some small farms initially replaced forests (Danziger 1979), by 1930, agriculture was scarcely present $(\sim 0 \%)$. The population grew from 695 in 1890 to reach a local maximum of 1288 people in 1920 (85.3\% increase; Fig. 7B). Allotment drew some off-reservation tribal members to the reservation (Morrison 2002), and natural increase (number of births compared to deaths) contributed to population growth.

As annuity payments of the 1854 Treaty dwindled, the interplay of poverty, upheaval of traditional culture, and Indian Agency logging policies propagated an accelerating feedback. A tribal elder recalled, "But a good deal...of lands were alienated at that time, people were living in utter poverty... Some people sold the stumpage, and other people sold the land itself" (J. D. Rose, tribal elder, Bad River Band of Lake Superior Ojibwe, personal communication; also Loomer 1954). As individual tribal members confronted poverty, economic conditions encouraged them to sell the valuable pines on their allotments, promoting forest removal.

2. Modernization (1930-1950)

After the reservation mill closed (1921), poverty deepened (ACLUPC 1941, Godfrey 1996, BRNRD 2001) and the tribal population declined (1920 to 1930 demographic change: 1288 to 1030 residents, or $-20 \%$ ). To spur economic development, the Indian Reorganization Act of 1934 (Section 6) directed sustained yield management. Agency foresters interpreted this legislation as a directive to apply short-rotation, even-aged management to the aspen-birch stands (1950 landscape proportion: 72.6\%; SteenAdams et al. 2007).

The bureaucratic approach to forest management also affected agency-community trust. Tribal members became increasingly disconnected from forest management decisions (BRNRD 2001). While even-aged management can be an appropriate silvicultural 
Fig. 6. Land ownership composition of the Bad River Indian Reservation, Wisconsin, at three times: 1917, 1958, 1986.

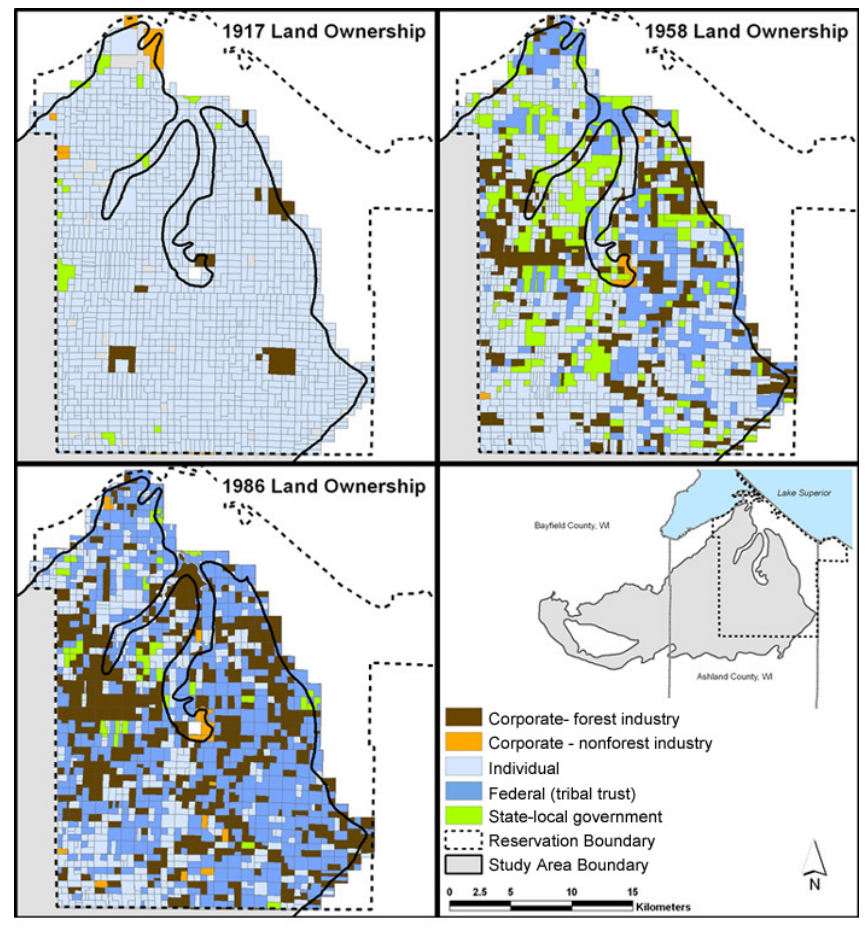

practice, the application at Bad River did not fit culturally (Godfrey 1996, BRNRD 2001, Doolittle 2001). Clearcuts essentially eliminated reforestation of the historic conifer component (e.g., white pine), a forest type of much greater cultural value to the tribe (BRNRD 2001, Steen-Adams et al. 2007)

Tribal population fell by $49.6 \%$ between 1920 and 1960 from 1288 to 650 residents. The ecological disturbance of intensive logging and fire, in combination with the assimilation policy to convert old-growth forest to farmstead, initiated an upheaval of the tribal culture and economy (Danziger 1979). The tribal outmigration is likely a lag effect of cumulative ecological and social factors that layered over one another over a half-century: forest alteration, social system unraveling, and widening disconnection from the land base.

\section{Industrial/mixed economy period (1950-1990)}

An accelerating feedback predominated in this period: tribal poverty and an expanding agency-community rift intensified forest harvest. Management decisions became more maladapted to tribal cultural values. Aspen rotations grew shorter: in 1973, the BIA harvest policy changed the minimum merchantable log height from $7.3 \mathrm{~m}$ ( 24 feet, or 3 "sticks") to $2.4 \mathrm{~m}$ ( 8 feet, or 1 "stick"). This promoted land covers characteristic of even-aged management seres (shrub-herb: 1950, 5.9\%; 1990, 21.6\%; aspenpaper birch: $1950,72.6 \% ; 1990,37.3 \%$; boreal: $1950,11.8 \% ; 1990$, $35.3 \%$ ). In the late $1970 \mathrm{~s}$, salvage harvest of Dutch elm diseaseaffected elms along river bottomlands (approximately 65 thousand board-feet [MBF] from 1600 acres) left an "indelible
Fig. 7. Coupled human and natural systems elements of the Bad River Indian Reservation, Wisconsin, 1860-1990. (A) Landscape composition: land-cover change of old-growth white pine-dominant stands, 1860-1990. Source: modified from Steen-Adams et al. (2011). (B) Human population, 1890-1990.

A

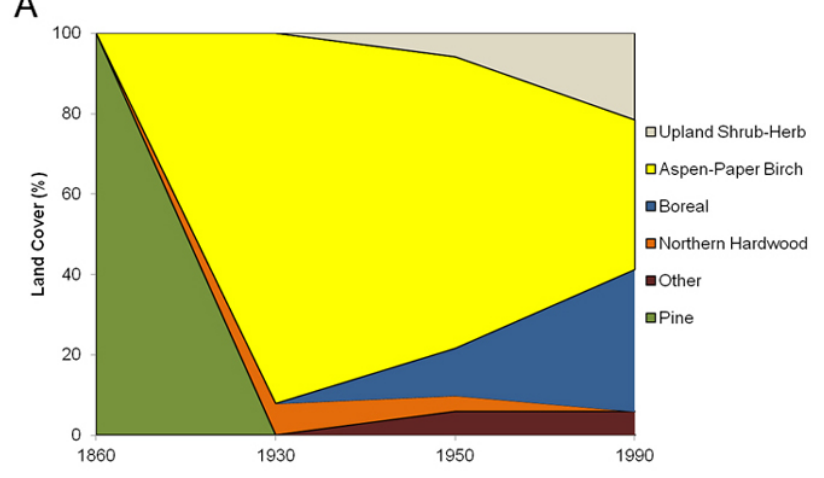

B

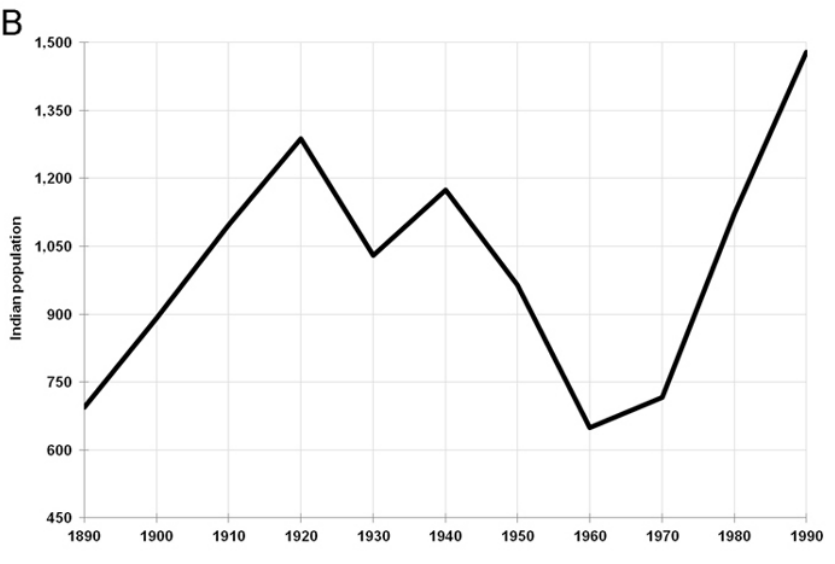

impression" on some tribal members (Godfrey 1996; J. D. Rose, tribal elder, Bad River Band of Lake Superior Ojibwe, personal communication), though many others approved of the salvage sale.

Between 1960 and 1990, the tribal population grew from 650 to 1478 residents $(127 \%)$. A combination of social and economic factors likely drove this demographic change (P. Loew, University of Wisconsin-Madison and member of Bad River Band of Lake Superior Ojibwe, personal communication). Failed promises of urban relocation and disillusionment with city life set the stage for reservation homecoming. Employment opportunities expanded in association with the 1992 opening of the Bad River casino. As occurred across Indian Country, casinos provided the practical economic means for disillusioned urban Indians to return home (Johnson 2009). The growth in the reservation tribal community, bolstered by Indian self-identification of the American Indian Movement, reinforced cultural values.

Tribal discontent with Agency forest management led to protests and development of a Tribal Forestry Department in 1982. A tribal elder recalled a protest in the 1980s: "Well, [the] Bad River Ogichida [an activist group]... went down and blockaded ... Elm Hoist Road ... where they were going to do some clear cutting 
along the Bad River..., and they shut that project down" (J. D. Rose, tribal elder, Bad River Band of Lake Superior Ojibwe, personal communication).

Political action eventually catalyzed institutional change. Development of the Bad River Natural Resources Department (BRNRD) promoted culturally adapted forestry practices, which supplanted conventional resource management. The tribe's Integrated Resource Management Plan (IRMP) articulates a management paradigm shift. Whereas tribal forests had been managed as a Timber Production Area (BRNRD 2001:21) that emphasized economic return, the IRMP vision is to "maintain... ecosystems for at least the next seven generations, while providing resources at a sustainable level of harvest."

Long-term feedbacks on the nonindustrial private forest zone Over the 1860-1990 time span in the NIPF zone, interactions between humans and environmental conditions fluctuated between accelerating and stabilizing feedback dynamics in response to the relative influence of LEK, land-use policy, community organization, and economic factors.

\section{Frontier/Euro-American settlement/imposed assimilation (1860-1930)}

On the NIPF zone, land-use history since Euro-American settlement has influenced the current forest landscape conditions. Forest harvest completely removed the old-growth pine $(100 \%$ of study sites pine-dominant in 1860 vs. $0 \%$ pine-dominant in 1930 ; Fig. 8A). In a regional context, NIPF zone harvest occurred before Indian reservation harvest (e.g., logging era underway by the 1877 connection of the Wisconsin Central Railway to Ashland, Wisconsin; Holzheuter 1986). Reforestation by aspenpaper birch was one of two main landscape change processes (1930 landscape proportion: 63.6\%). Agricultural activity, which settlement promoted, was the second main landscape change process (1930 landscape proportion: $29.5 \%$ ). Together, these two processes initiated the current forest-agriculture mosaic.

The population grew by $26.6 \%$ between 1890 and 1920 from 9412 to 11,916 inhabitants (Fig. 8B). The cleared land and promotional materials encouraged settlement, often by immigrants (Fig. 9A; Vogeler 1983).

State-employed agricultural agents and the farmer landowners attempted to prop up this precarious system. Soils, logging history, market conditions, and climate presented challenges to cutover farmers, including stumps and root masses that required hazardous removal techniques (Ely et al. 1920), acidic and easily compacted clay soils (Delwiche 1913, ACLUPC 1940), and fluctuating agricultural product markets (Fig. 9B). Adaptations developed, for instance, employment of nitrogen-fixing cover crops to ameliorate soil (Delwiche 1913, Ely et al. 1920).

\section{Modernization (1930-1950)}

During the modernization period, the aspen-paper birch component of the forest mosaic declined (1950 landscape proportion: $47.7 \%$ ). Agriculture-grassland land cover increased from 29.5 to $38.6 \%$. This is a notable increase compared to regionwide decline (Rhemtulla et al. 2007), associated with farm abandonment (Carstensen 1958). Furthermore, agricultural land increased despite a $34 \%$ population decrease from 11,916 in 1920 to 7856 in 1950. Agricultural land-cover change may be a lag effect of the interaction between 1900-1920 population growth, local economic organization (dairy cooperatives; Bell 1941; B. Kurki, life-long Ashland County resident and dairy farm family member, personal communication), and agricultural consolidation policies (e.g., rural zoning). Farm operations shifted from row-crop agriculture to dairying, allowing pastures and grasslands to replace plowed fields (ACLUPC 1941). To survive in this system during this period, a farm needed to expand. Farmers of the frontier-settlement period either increased farm size or left.

Fig. 8. Coupled human and natural systems elements of the nonindustrial private forest (NIPF) zone, 1860-1990. (A) Landscape composition: land-cover change of old-growth white pine-dominant stands, 1860-1990. Source: modified from Steen-Adams et al. (2011). (B) Human population, 1890-1990.

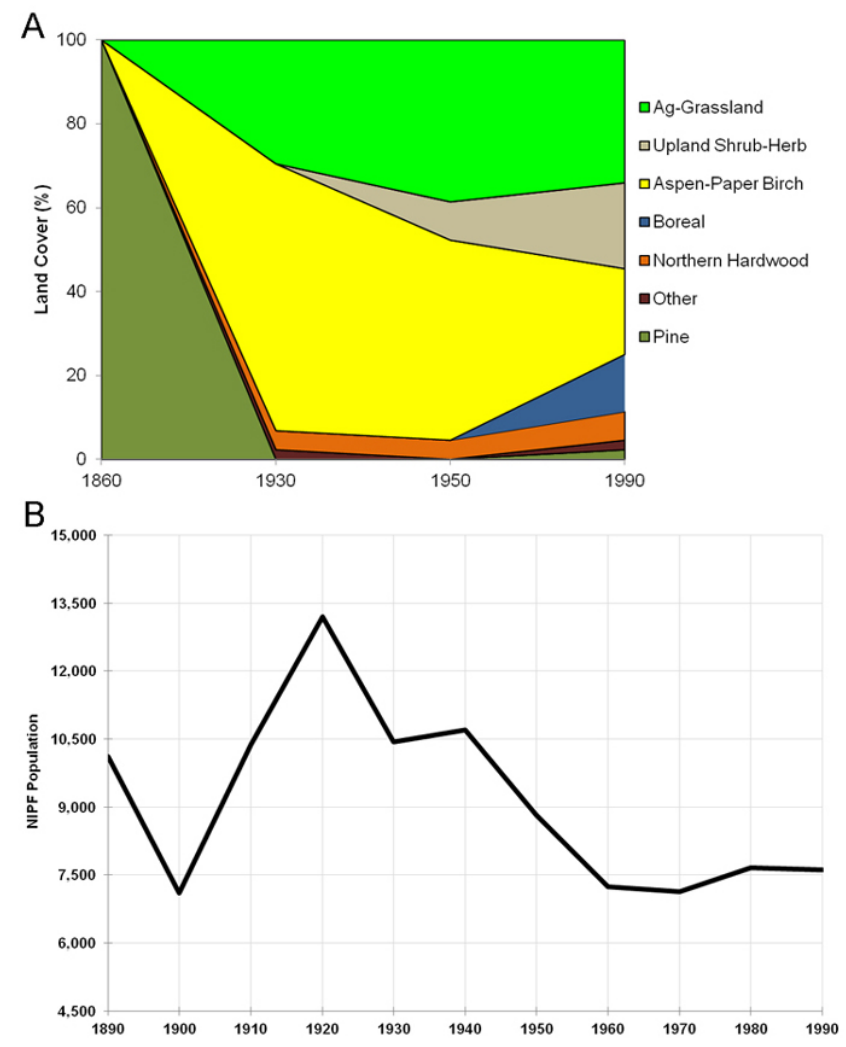

3. Industrial/mixed economy (1950-1990)

Outmigration continued through 1990 , leading to a $21.9 \%$ population decrease relative to 1950 from 7856 to 6134 inhabitants. Population decline promoted agricultural land retirement from $38.6 \%$ (1950) to $34.1 \%$ (1990) of the landscape.

At the individual farm operation scale, financial pressures propagated an accelerating feedback between farm size, indebtedness (debt load), and environmental condition. When farmers retired, others bought their land, increasing average farm size. Expanded farms typically included noncontiguous parcels, including property and rented land (K. Lindquist, Ashland County Board Chair and dairy farmer, personal communication; G. Mika, Ashland County Board, Ashland County Land Conservation Committee, and farmer, personal communication). 
Fig. 9. Promotional materials depicting farmstead development in the northern Wisconsin cutover region. (A) "Farm home," approximately 1895. H. J. Perkins, photographer. Settler family posing on a road adjoining their homestead; stumpland is in foreground and forest in background. Image ID: WiH-94748. (B) "A. G. Beebe farm," September 26, 1895. H. J. Perkins, photographer. View of the A. G. Beebe farm in Bruce, Wisconsin, with stumpland in the foreground. Image ID: WiH-3346. Image source: W. A. Henry, 1896, Northern Wisconsin: a hand-book for the homeseeker. (A and B) Reprinted with permission of the Wisconsin Historical Society, Madison, Wisconsin, USA.

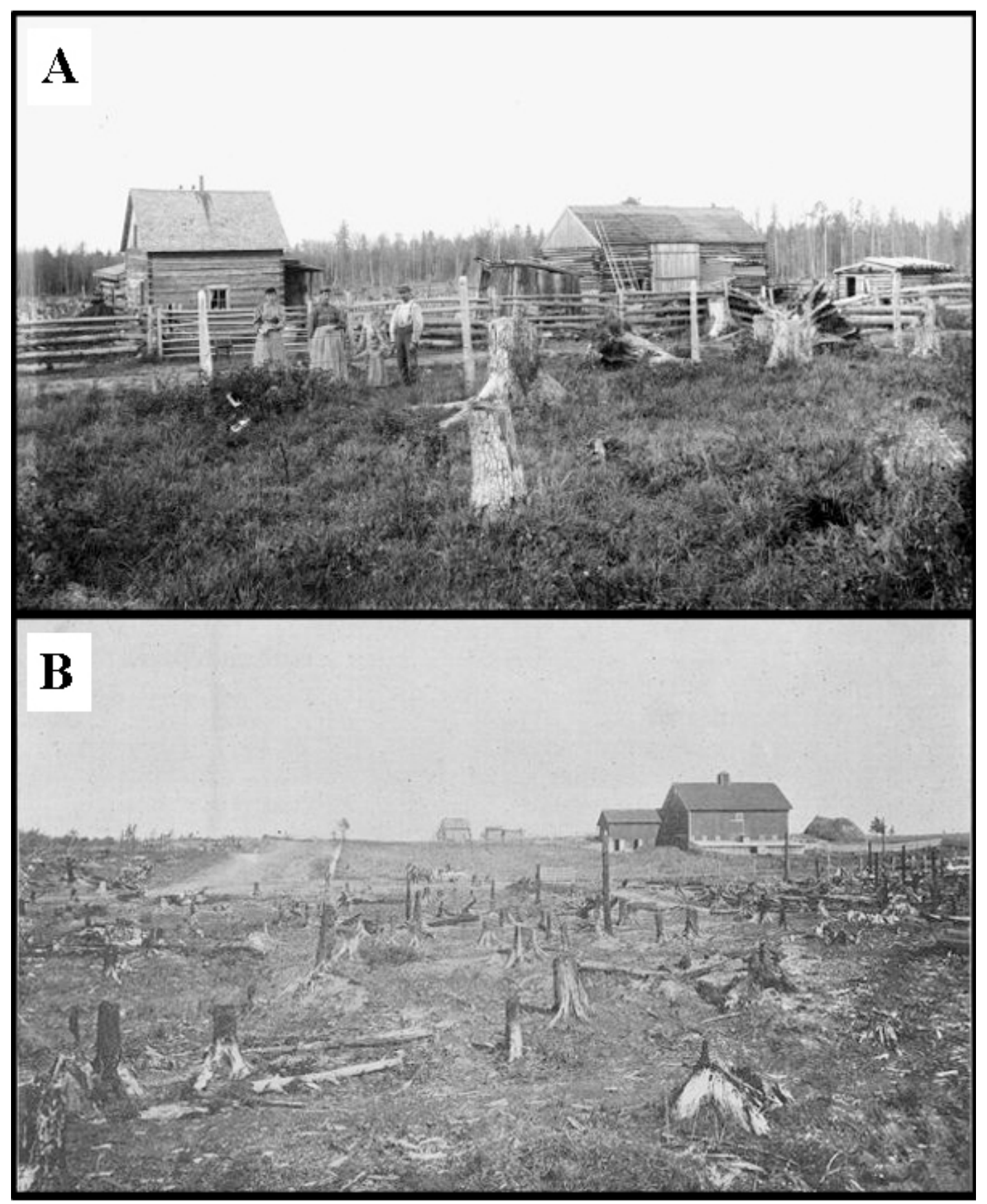


Increased farm size and equipment often led to unsustainable debt loads, however, which prevented many farmers from keeping their land in the family farm, despite ardent wishes to do so. One thirdgeneration farmer observed, "... the concept of farming always was that when we started farming, we would sell it to the next generation, as my dad bought from his dad and I bought from my parents. That one day you sell it and then you retire on that....[O]ur debts are so big that if we sell it we just pay our debts off, we still don't have anything to retire on. And this is the concept that has happened in most agriculture families. They quit farming at 45 or 50 to go and find a job so that they can have something in retirement.... I would rather keep the kids on the farm, I would rather give it to the next generation, I may not be able to afford that... [T] hey're telling me, I can't make a living on the farm dad, because I watched you and you don't have nothing put away (G. Mika, Ashland County Board, Ashland County Land Conservation Committee, and farmer, personal communication). Cost-sharing funds encouraged farmers to increase farm size through installation of drainage ditches. Farmers responded by ditching their fields, which put more land into production (K. Lindquist, Ashland County Board Chair and dairy farmer, personal communication; G. Mika, Ashland County Board, Ashland County Land Conservation Committee, and farmer, personal communication).

Soil erosion was an unintended consequence of farm expansion on the fragile clay plain soils. A third-generation farmer observed, "We took this water, and we diverted it everywhere. Well, along with the diverting of the water came erosion... It's amazing, back in the ' $50 \mathrm{~s}$, ' $60 \mathrm{~s}$, and ' $70 \mathrm{~s}$, until we started getting the cattle off, when it rained 2 or 3 inches..., that river was red [from clay soil erosion] for weeks" (G. Mika, Ashland County Board, Ashland County Land Conservation Committee, and farmer, personal communication).

In the 1980s, a turning point occurred. Agricultural scientists observed that erosion from ditching harmed fish habitat and urged extension agents to stop promoting drainage channels. A new wetland restoration incentive program began, which was a second contributor to the 1950-1990 agriculture land-cover decline. Farmers responded by decreasing cultivation. This allowed revegetation by nonagricultural land covers: upland shrub-herb increased from 9.1 to $20.5 \%$ of the landscape, and boreal forest increased from $0.0 \%$ (as dominant species) to $13.6 \%$. Erosion-prone land cover decreased, thereby stabilizing the feedback.

\section{DISCUSSION}

\section{Utility of historical framework to explain long-term coupled human and natural system feedbacks and current forest landscape conditions}

As our results show, an environmental history framework can illuminate linkages between the historical basis of past management decisions, forest ecological effects, and social responses. Our study demonstrates how feedbacks develop over time and can accelerate under certain conditions, leading to unintended consequences that differ starkly from policy visions. These results support our overall argument that a historical perspective can reveal applied insights that promote learning and adaptation and increase system resilience that would not be visible through a short-term, nonhistorical analysis alone.
Legacy effects and lagged interactions

The main legacy effect revealed by our analysis is the persisting effect of primary forest harvest and associated catastrophic fire on secondary forest composition. On both the Indian reservation and the NIPF zone, reforestation occurred, yet composition differed significantly from the previous compositional state (Figs. 7A, 8A). The change in landscape composition from dominance by mature conifer to hardwood that had occurred by 1930 has largely persisted through 1990. This finding generally corresponds with previous studies of the northern Great Lakes region (White and Mladenoff 1994) and elsewhere in the Laurentian Mixed Forest Province of the northeastern United States (Foster et al. 1998).

Relating the timing of mid-20th century forest management to the span of Great Lakes forest history is crucial to appreciating the legacy effect of this latter alteration (Mladenoff and Pastor 1993). Intensive forest management was continuously applied when forests were in a stage of early successional reforestation. This timing prevented diverse successional pathways from developing, greatly simplifying broad-scale forest structure. The ecological significance of these legacy effects can be appreciated at a regional scale: forest structure and dynamics shifted from dominance by species characteristic of the Great Lakes northern hardwood-mixed conifer region to that of generalist, early successional species (following Mladenoff and Pastor 1993). Our results correspond with investigations of the Great Lakes region (Mladenoff and Pastor 1993, Crow et al. 1999) and sub-region (Radeloff et al. 1999). In the broader regional context, our results contribute to evidence of regional loss of biodiversity.

The observed long-term forest landscape changes are not a function of biophysical legacy effects alone, however; rather, our framework revealed the role of the social component as an interacting factor that contributed to landscape change. BIA managers and NIPF landowners of the 1930s responded to forest alteration that began after 1860; these responses conditioned reforestation processes during the 1930-1950-1990 intervals and consequent landscape composition change. Mid-20th century decisions to apply industrial forestry clearcuts to maintain aspen and other pulpwood forest types occurred in response to the predominance of this species in the 1930 landscape state. This decision promoted the maintenance of aspen-paper birch. In combination, this series of forest compositional change, management response, and subsequent compositional change propagated a positive feedback among pulpwood species and the pulpwood industry, to the exclusion of other forest types, resulting in a loss of biodiversity and the exclusion of other forest cultural values.

Our framework also highlighted previously obscure lag effects of ecological alteration on social condition. On the Indian reservation, after the white pine timber was removed, poverty enveloped the community (Danziger 1979). Many tribal members sold the cutover land. Impoverished and separated from the land base, the population declined by nearly 50\% (49.6\%) between 1920 and 1960 (Fig. 7B). Intensive management of the reforested hardwoods as short-rotation clearcuts generated interest by pulpwood products companies. Between 1958 and 1986, forest products corporation ownership nearly doubled (75.9\% increase), accounting for nearly one-third of the reservation land base within the project study area by 1986 (29.9\%; Table 1). Conversely, 
individual ownership, which is primarily held by tribal owners, declined from $91.4 \%$ (1905) to $24.1 \%$ (1986). The framework enabled us to trace lag effects of ecological alteration on social condition that had not previously been apparent.

\section{Revealing unintended consequences to inform adaptation}

Detecting unintended consequences is one of the most powerful ways that environmental historical analysis of CHANS feedbacks can inform adaptation to promote sustainability and human wellbeing (Langston 1995, Lambin and Geist 2003, Millennium Ecosystem Assessment 2005). Characterization of linkages between environmental historical factors (levels 3 and 4), humannature interactions, landscape alterations (level 1), and consequent human effects (level 2) helps investigators systematically probe unintended consequences (Figs. 1 and 4). Application to policy and planning lies beyond simply comparing actual vs. target outcomes: : learning how past worldviews, economic systems, or other historical factors propagated CHANS feedbacks, which led to unexpected outcomes, can inform presentday efforts to adapt and improve environmental policy and planning.

Outcomes for people and nature significantly differed from policy objectives and paradigm visions in the northern Wisconsin study area. A major system surprise developed over a century (18601960) in relation to the Indian assimilation policy vision to transform the reservation social-economic-ecological system from one based in traditional uses of forest, wetland, and aquatic resources (Fig. 3) to one based in forest commodity production (Fig. 5A). The Indian agency fulfilled the emergent vision to transform the old growth pine-dominant forest to sustained-yield hardwood units (Fig. 7A). However, policy architects did not anticipate the social effects that would unfold: land loss (Table 1) driven by tribal poverty, disconnection from the land base, and outmigration.

A policy and management implication of this finding is that approaches that fail to tailor forest management to social structures and values of the host community run the risk of generating outcomes much worse than initial conditions. We stress that values and structures should be understood in a dynamic, not static, way. Other investigators of tribal communities highlight the importance of maintaining the dynamic web of relationships between people and the land (Davidson-Hart and Berkes 2003). Thus, a sound approach to adaptive management requires an on-going process of community engagement.

\section{Turning points and periods in system dynamics: characterizing} patterns of continuity and change

Historical period functions as an organizing structure to demarcate intervals of continuity and change. The framework helps relate breakpoints in predominant worldview and system of governance and economy to management decision outcomes, landscape change (system states $t_{0}, t_{1}, \ldots t_{\mathrm{n}}$ ), and social feedbacks. The utility to CHANS investigators is to reveal a sequence of intervals characterized by distinctive human-forest landscape interactions and to identify major shifts in forest landscape structure and function.

Significant shifts in the northern Wisconsin social-ecological system developed over the 130-year timespan of this study. During the settlement/imposed assimilation period (1860-1930), human activity extracted timber from the mature forest to provide building materials and expand the regional and national economy. After 1900, cutover, cleared land promoted agricultural settlement, leading to population increase on the NIPF zone, and for different historical reasons, on the Indian reservation. During the modernization period (1930-1950), the worldview of system actors shifted from resource extraction to sustained-yield management, intensively so on the reservation and more moderately on the NIPF zone. Reservation foresters developed sustained yield units to maximize harvest of a lower grade resource. NIPF owners managed the land to cultivate agricultural and forest products. Population declined. During the industrial/ mixed economy period (1950-1990), forest management became yet more intensive on the reservation (i.e., shorter rotations), whereas off-reservation, a mix of economic activities and land uses was applied, including forestry, agricultural, and recreational land uses. The divergent practices of the later 20th century can be understood in the context of dissimilar socioeconomic and institutional contexts between the two ownerships: on the reservation, an industrial forestry paradigm predominated, whereas on the NIPF zone, diverse land-use visions intermixed, including both industrial forestry and an agrarian vision.

Two major turning points structure forest landscape change on this Wisconsin landscape. After 1860, original forests were removed, resetting landscape composition through processes of reforestation and agricultural development. Then, around 1930, revegetation occurred. The landscape history of our study area, consisting of phases of deforestation, a multi-decade period of cultivation, and finally, reforestation, corresponds with those observed regionally (White and Mladenoff 1994). A comparison can also be made across regions. Our results closely parallel landscape dynamics of New England approximately 1 century earlier (Foster et al. 1998).

The process of applying historical periods to our study also revealed shifting demographic-landscape relationships over the 130-year study timespan. From 1860 to approximately 1960 , population and landscape change are inversely related. As population increases, primary forest decreases. On both ownerships, the mid-20th century population maximum (1920) corresponds with the maximum land-cover change (1930; Figs. 7 and 8). After 1920, as the population decreased, boreal forest and upland shrub-herb land covers increased as forest succession and limited agricultural abandonment occurred. Through the phase of population increase, a similar relationship between population and landscape dynamics applies to New England (Foster et al. 1998).

\section{Forest ecological and management significance}

Community goals for forest landscape restoration initially motivated our selection of this northern Wisconsin study site. The tribe's Integrated Resources Management Plan calls for an ecosystem management approach, including forestry practices that protect waterways, especially the culturally significant, ecologically sensitive Kakagon Sloughs, some forest commodity production, and restoration of ecosystem components that have been reduced or eliminated since Euro-American settlement (e.g., white pine, white cedar; Spots 1994, BRNRD 2001). The community vision (NIPF zone) for landscape restoration shares similar goals (Trout Unlimited-Wisconsin and Friends of White River 2004). 
Our results indicate that alteration of regionally characteristic landscape mosaic dynamics has occurred. Our 130-year, foursnapshot forest chronology shows that after old-growth forest clearance, patch dynamics mainly consist of open, early successional, and mid-successional forest land covers (Figs. 7A and 8A). This situation contrasts with historic forest dynamics of the study area, which prominently featured mature, later successional stands of white pine (Mladenoff and Pastor 1993). The $>1000$-year interval disturbance regime on the low-elevation, moist, clay plain (1844 yr, combined wind and fire; $5363 \mathrm{yr}$, standreplacing fire; Schulte and Mladenoff 2005) would have promoted the mature forest component. This change is ecologically significant because ecological functionality depends on maintenance of patch dynamism, e.g., diversity of successional pathways, not simply diversity metrics of a given time state (Mladenoff and Pastor 1993).

Restoration of forest landscape composition will require progress toward restoration of the disturbance regime. Since 1930, commodity forestry practices have largely governed the disturbance regime on the clay plain. A similar reordering of the disturbance regime has developed on landscapes elsewhere in the region (Radeloff et al. 1999). Following restoration strategies developed for this northern Great Lakes social-ecological region, clay plain restoration could employ landscape design principles (Mladenoff et al. 1994). A core conservation area, consisting of the remaining scattered white pines of the historic, drier-site "pine basket", would function as a restoration starting point (Clark and Niese 2000). Away from the core conservation area in an outer zone largely comprising early successional stands, clearcut practices would be modified to partial harvests and include mixed species rotations. Between the conservation core and the outer zone, the forest matrix would employ uneven-aged management, focusing on existing mid-successional species.

Practically speaking, addressing the influence of land ownership pattern on forest structure and processes is a forest restoration prerequisite. Still today, managers contend with the fragmentation and loss of the reservation land base that developed through the 20th century. Tribal natural resource managers recognize the persisting effects that inhibit coordinated, reservation-wide management and planning. This insight has promoted landscape-scale planning to prioritize alienated land reacquisition and restoration (BRNRD 2001).

\section{Insights for coupled human and natural system research on multiple-ownership forest landscapes}

In this study system, we found that actors of a multiple-ownership landscape can propagate heterogeneous social-ecological feedbacks. Foresters and other system actors responded differently to the post-cutover forest composition, contributing to variation in land-cover change among tribal and NIPF ownerships, as reported elsewhere (Steen-Adams et al. 2011). A main difference is the greater proportion of nonforest land cover (e.g., agriculture-grassland, shrub-herb) on private land, which has been found in other Great Lakes region investigations (Crow et al. 1999). The other main difference is the dominance by aspenpaper birch on tribal land at all three post-cutover time states (1930-1950-1990). On the Indian reservation, foresters decided to manage the reforested hardwoods as sustained-yield forest units. On the NIPF zone, landowners converted nearly one-third
(29.5\% in 1930) of the landscape, largely composed of cutover stumplands, to field and pasture, resulting in a mosaic of agriculture and secondary forest.

To understand why these heterogeneous ecological feedbacks developed, we examined social historical factors. Variance in historical management paradigm, institutional arrangements, economic system, and culture were important factors (compare Figs. 5 and 9; also see Fig. 3). Within the BIA Division of Forestry, an industrial forestry model developed. A distinctive influence on the BIA forestry program was the legacy of failed early 20th century assimilationist policies, which left administrators searching for strategies to support foundering reservation economies (Newell et al. 1986, Godfrey 1996). Managing aspenpaper birch stands on short rotations for sale to pulpwood products companies fit this model. On the NIPF ownership and across the region, agricultural landowners contended with a variety of financial, market, edaphic, and climatic factors that led to widespread farm abandonment and subsequent reforestation on many sites (Gough 1997). Still, early 20th century actions to develop institutions (e.g., community insurance organizations), agricultural economic systems (e.g., dairy cooperatives), and a community culture based on mixed agriculture and forestry, combined with farm consolidation policies and rural zoning, helped maintain some agricultural land use on the Lake Superior clay plain (B. Kurki, life-long Ashland County resident and dairy farm family member, personal communication; F. Jolma, life-long Ashland County resident and dairy farmer, personal communication; G. Mika, Ashland County Board, Ashland County Land Conservation Committee, and farmer, personal communication).

Varying actor decisions (circa 1930) introduced feedback effects on landscape change that played out through the 20th century, which help to account for present-day landscape heterogeneity among ownerships. BIA forester decisions to develop industrial, sustained-yield units set in motion interest by forest products companies to purchase tribal land, which in turn promoted the continuation of even-aged harvests for the next six decades. On the NIPF zone, somewhat different social factors governed past land-use decisions, propagating distinct long-term effects. Comprehensive county land-use planning committees (which corresponded with the Wisconsin State Planning Board and the Wisconsin Land Economic Inventory) mapped agricultural, forest, and other land uses, and made soil amelioration prescriptions based on surveys of soil and socioeconomic conditions (ACLUPC 1941). In this Lake Superior-moderated environment, unlike more agriculturally marginal areas of Wisconsin, county land-use planning may have helped stabilize the regionally dominant accelerating feedback between rural poverty, outmigration, and farm abandonment, helping to account for the late 20th century forest-agricultural landscape mosaic.

The framework contributes insights about multiple-ownership systems that are relevant to current forest landscape management and restoration in two ways. One, investigators expand capacity to characterize the variation of underlying social processes (e.g., inmigration/outmigration, economic development, community organization) that drive decision outcomes in relation to ownership. As this case study demonstrates, environmental 
historical factors can influence landowner decisions; these responses in turn affect current landscape conditions. Our framework structures the consideration of historical factors that vary with ownership compared to those that apply at broader geographic scales.

Two, the framework helps pinpoint historical ecological turning points when landscape trajectories diverged among ownerships. Many forest landscape issues require coordination among ownerships (e.g., National Cohesive Wildland Fire Management Strategy, as required by the Federal Land Assistance, Management and Enhancement [FLAME] Act of 2009; Interior, Environment, and Related Agencies Appropriations Act, 2010, Title V). Coordinating restoration across ownerships requires understanding social causes of variation in landscape condition. A foundational step to accounting for present-day landscape heterogeneity lies in identifying turning points when differing actor decisions and alterations initiated divergent ecological pathways.

\section{Ownership as a variable to examine long-term social-ecological feedbacks}

Our study also examines the validity of employing ownership as a social variable representing human decision-making in CHANS models. Ownership variables are frequently employed in landscape models (Mladenoff et al. 1993, Turner et al. 1996, Spies et al. 2007). Our study demonstrates that land ownership can validly represent decision-making structure, culture, and knowledge systems in CHANS models when treated as a categorical variable and interpreted with historical analysis.

Ownership can be a tractable, spatially explicit variable to model diverse social histories in three ways. One, ownership class can indicate heterogeneous decision-making structures. This is useful to CHANS analysis because the decision-making structure (e.g., hierarchical, collaborative) can affect decision outcomes, and in turn, feedbacks. On the Lake Superior clay plain, for example, a hierarchical structure drove management in one zone, whereas a more autonomous structure predominated on the other. The maladaptive feedback that developed on the reservation is integrally tied to its political history: the hierarchical structure generally contributed to ignoring the values of one group, the tribal members, and implementing culturally incongruent management practices.

Two, ownership class can enable investigators to assess the influence of culture (e.g., values, mode of livelihood) on forest landscape condition, as land-use practices in the NIPF zone demonstrate. For instance, the early 20 th century agricultural land-use practices of Scandinavian and German immigrant settlers are a manifestation of the motivating vision and tradition, i.e., that of the independent, small-scale, yeoman farmer.

Three, ownership class can reveal the dominant knowledge system. For instance, conventional resource management informed decisions on reservation forests, whereas local ecological knowledge prevailed on the NIPF zone, leading to differing feedbacks. However, we stress that a plurality of knowledge systems existed within the reservation landscape. Still, one knowledge system prevailed over others because of the hierarchical decision-making structure.

Besides ownership class, land tenure characterization would provide more nuanced insights to examine forest sustainability questions, especially for investigations of forests in developing nations (Ostrom and Nagendra 2006). Land tenure rights codify how individuals and groups access forest resources. Access rights might vary in relation to specific forest goods, services, or seasonality. The history-CHANS framework could be extended to examine how and why shifting land tenure arrangements have influenced neighboring user groups' respective management decisions and, in turn, current conditions and restoration options.

In some respects, however, there are limits to the social complexity that ownership class can represent in social-ecological models. First, on some ownerships (e.g., tribal), forestry objectives of the primary decision-maker may have differed from those of the owner/trustee. Interpretation of the results must account for this situation. For example, in our Wisconsin study, the forestry goals of the BIA, which dominated decision-making outcomes, frequently diverged from those of many tribal members. Autonomy of local residents to influence forest management differed greatly between the NIPF and reservation zones. This asymmetry must be considered in the interpretation of the forest landscape change results. The fiduciary responsibility of the agency to the tribe further complicates the analysis. Second, the factors associated with ownership history (e.g., past ownership class, parcel turnover rate) might also be misattributed to the current ownership. Instead, the persisting effects of past ownership might be a major driver of current forest condition. Third, when a public or tribal administrative unit encompasses private holdings that are not represented in the model, the paradigms and practices of the two ownerships may be conflated.

\section{CONCLUSIONS}

Current and future forest landscape and social conditions are influenced by the cumulative, unfolding history of socialecological interactions. The Bad River Reservation and NIPF zone on the Lake Superior clay plain is a good case study to demonstrate how the history-CHANS framework can inform broad-scale landscape management and restoration. At the broad scale of the clay plain, the sharp reduction of regionally characteristic mature forest species (white pine), contributing to reduction of biodiversity and ecological functionality, is partially a legacy of late 19th century national objectives for EuroAmerican settlement and development. Yet, it is through the process of considering ownership environmental history that we glean precise insight into heterogeneous decision outcomes of system actors and, in turn, landscape complexity. The decisions of Indian reservation forest managers were driven by agency policies and management paradigms in interaction with the social-ecological environment. Likewise, land-use decisions of NIPF owners were shaped by their dominant worldview in interaction with the social-ecological environment. Locally distinct social-ecological systems (forestry, mixed agrictultureforestry) developed, leading to variances in disturbance regime and departure from historic conditions.

Of relevance to forest policy, the northern Wisconsin case study demonstrates how the framework can help distil insights from unintended consequences that inform adaptation. Policy objectives and consequent management interventions can lead to unintended feedbacks that take a long time to develop and become apparent. For instance, the demographic decline and adverse social effects of late 19th century visions to impose assimilation 
onto native culture through forest landscape conversion did not fully play out until at least 1960 . The process of relating management objectives emergent from the dominant worldview (framework levels 3 and 4) to actual outcomes through time provides perspective to assess policy and make corrective adaptations.

These results demonstrate that environmental historical factors operating at multiple geographic scales, across a sequence of distinct periods, have conditioned social-ecological feedbacks and, in turn, forest landscape conditions. Applying a historical framework to CHANS investigation generates practical knowledge to inform forest landscape restoration policy and management.

Responses to this article can be read online at: http://www.ecologyandsociety.org/issues/responses. php/6930

\section{Acknowledgments:}

We are grateful for the suggestions of three anonymous reviewers whose input significantly improved the manuscript. Our research was supported by the USDA Forest Service, the National Science Foundation Coupled Human and Natural Systems Program (NSF Grant CNH-1013296), the University of New England, the National Science Foundation IGERT Grant 9870703 (Human Dimensions of Social and Aquatic Systems Interactions), a USDA McIntire-Stennis research grant to $N$. Langston, and a grant from the Wisconsin Department of Natural Resources Forestry and Science Services to D. Mladenoff. We thank the Bad River Band of Ojibwe, especially the Bad River Natural Resources Department; the Nature Conservancy Chequamegon Bay office; the oral history interview participants; T. Sickley and P. Weum for assistance to develop the land ownership-land cover GIS; S. Schultz, D. Templar, and C. Yang; and the University of Wisconsin-Madison Forest Landscape Ecology Lab.

\section{LITERATURE CITED}

ACLUPC [Ashland County Land Use Planning Committee]. 1941. Unified land use planning report. Ashland County Land Use Planning Committee, Ashland, Wisconsin, USA.

Beard, T. D. Jr., S. P. Cox, and S. R. Carpenter. 2003. Impacts of daily bag limit reductions on angler effort in Wisconsin Walleye Lakes. North American Journal of Fisheries Management 23 (4):1283-1293. http://dx.doi.org/10.1577/M01-227AM

Bell, F. C. 1941. Farmer co-ops in Wisconsin. St. Paul Bank for Cooperatives, St. Paul, Minnesota, USA. [online] URL: http:// digital.library.wisc.edu/1711.dl/WI.FarmerCoops.

Bentley, J. H. 1996. Cross-cultural interaction and periodization in world history. American Historical Review 101(3):749-770. http://dx.doi.org/10.2307/2169422

Berkes, F., J. Colding, and C. Folke. 2000. Rediscovery of traditional ecological knowledge as adaptive management. Ecological Applications 10(5):1251-1262. http://dx.doi. org/10.1890/1051-0761(2000)010[1251:ROTEKA]2.0.CO:2
Berkes, F., and C. Folke, editors. 1998. Linking social and ecological systems: management practices and social mechanisms for building resilience. Cambridge University Press, Cambridge, UK.

Berkes, F., C. Folke, and M. Gadgil. 1995. Traditional ecological knowledge, biodiversity, resilience and sustainability. Pages 269-287 in C. A. Perrings, K.-G. Mäler, C. Folke, C. S. Holling, and B.-O. Jansson, editors. Biodiversity conservation. Springer, Dordrect, The Netherlands. http://dx.doi.org/10.1007/978-94-0$\underline{11-0277-3 \quad 15}$

Berkes, F., and D. Jolly. 2001. Adapting to climate change: socialecological resilience in a Canadian western Arctic community. Conservation Ecology 5(2): 18. [online] URL: http://www. consecol.org/vol5/iss2/art18/.

Bolliger, J., L. A. Schulte, S. N. Burrows, T. A. Sickley, and D. J. Mladenoff. 2004. Assessing ecological restoration potentials of Wisconsin (U.S.A.) using historical landscape reconstructions. Restoration Ecology 12(1):124-142. http://dx.doi.org/10.1111/ j.1526-100X.2004.00285.X

BRNRD [Bad River Natural Resources Department]. 2001. Integrated resources management plan. Bad River Natural Resources Department, Odanah, Wisconsin, USA.

Burton, P. J., B. Eddy, L. Fähser, C. Messier, M. G. Reed, T. Spies, and R. Vides. 2010. Managing forested landscapes for socioecological resilience. Pages 401-439 in G. Mery, P. Katila, G. Galloway, R. I. Alfaro, M. Kanninen, M. Lobovikov, and J. Varjoand. Forests and society: responding to global drivers of change. IUFRO World Series Volume 25. International Union of Forest Research Organizations, Vienna, Austria. [online] URL: http://www.iufro.org/science/special/wfse/forests-society-global-drivers/.

Cadanesso, M. L., S. T. A. Pickett, and J. M. Grove. 2006. Dimensions of ecological complexity: heterogeneity, connectivity, and history. Ecological Complexity 3(1):1-12. http://dx.doi. org/10.1016/j.ecocom.2005.07.002

Carpenter, S. R., B. J. Benson, R. Biggs, J. W. Chipman, J. A. Foley, S. A. Golding, R. B. Hammer, P. C. Hanson, P. T. J. Johnson, A. M. Kamarainen, T. K. Kratz, R. C. Lathrop, K. D. McMahon, B. Provencher, J. A. Rusak, C. T. Solomon, E. H. Stanley, M. G. Turner, M. J. Vander Zanden, C.-H. Wu, and H. Yuan. 2007. Understanding regional change: a comparison of two lake districts. BioScience 57(4):323-335. http://dx.doi.org/10.1641/ $\underline{\text { B570407 }}$

Carpenter, S. R., and M. G. Turner. 2000. Hares and tortoises: interactions of fast and slow variables in ecosystems. Ecosystems 3(6):495-497. http://dx.doi.org/10.1007/s100210000043

Carpenter, S., B. Walker, J. M. Anderies, and N. Abel. 2001. From metaphor to measurement: Resilience of what to what? Ecosystems 4(8):765-781. http://dx.doi.org/10.1007/s10021-001-0045-9

Carstensen, V. R. 1958. Farms or forests: evolution of a state land policy for northern Wisconsin, 1850-1932. College of Agriculture Publication G2284. University of Wisconsin, Madison, Wisconsin, USA.

Charnley, S., A. P. Fischer, and E. T. Jones. 2007. Integrating traditional and local ecological knowledge into forest biodiversity 
conservation in the Pacific Northwest. Forest Ecology and Management 246(1):14-28. http://dx.doi.org/10.1016/j.foreco.2007.03.047

Cissel, J. H., F. J. Swanson, and B. J. Weisberg. 1999. Landscape management using historical fire regimes: Blue River, Oregon. Ecological Applications 9(4):1217-1231. http://dx.doi. org/10.1890/1051-0761(1999)009[1217:LMUHFR]2.0.CO;2

Clark, F., and J. Niese. 2000. An assessment of forest restoration opportunities on the Bad River Reservation, Wisconsin. Clark Forestry, Inc., Baraboo, Wisconsin, USA.

Cronon, W. 1991. Nature's metropolis: Chicago and the Great West. Norton, New York, New York, USA.

Cronon, W. 2004. Getting ready to do history. Carnegie Essays on the Doctorate. Carnegie Foundation, Palo Alto, California, USA. [online] URL: http://www.williamcronon.net/writing/ Cronon Carnegie Essay Getting Ready to Do History 2004. pdf.

Crow, T. R., G. E. Host, and D. J. Mladenoff. 1999. Ownership and ecosystem as sources of spatial heterogeneity in a forested landscape, Wisconsin, USA. Landscape Ecology 14(5):449-463. http://dx.doi.org/10.1023/A:1008084123874

Curtis, J. T. 1959. The vegetation of Wisconsin: an ordination of plant communities. University of Wisconsin Press, Madison, Wisconsin, USA.

Danziger, E. J. Jr. 1979. The Chippewas of Lake Superior. University of Oklahoma Press, Norman, Oklahoma, USA.

Davidson-Hunt, I., and F. Berkes. 2003. Learning as you journey: Anishinaabe perception of social-ecological environments and adaptive learning. Conservation Ecology 8(1): 5. [online] URL: http://www.consecol.org/vol8/iss1/art5/.

Delwiche, E. J. 1913. The culture of peas for seed and canning. Lake Superior Farmer 1(18):1.

Donahue, B. 2000. History, work, and the nature of beauty: a Massachusetts community forest. Journal of Forestry 98 (11):36-41.

Doolittle, T. 2001. Boreal forest restoration project: Bad River Reservation, Wisconsin. Bad River Tribal Department of Resource Management, Odanah, Wisconsin, USA.

Ely, R. T., B. H. Hibbard, and A. B. Cox. 1920. Credit needs of settlers in Upper Wisconsin. Agricultural Experiment Station Bulletin 318. University of Wisconsin-Madison, Madison, Wisconsin, USA.

Fischer, A. P., and S. Charnley. 2012. Risk and cooperation: managing hazardous fuel in mixed ownership landscapes. Environmental Management 49(6):1192-1207. http://dx.doi. org/10.1007/s00267-012-9848-Z

Fitzpatrick, F. A., J. C. Knox, and H. E. Whitman. 1999. Effects of historical land-cover changes on flooding and sedimentation, North Fish Creek, Wisconsin. Water-Resources Investigations Report 99-4083. U.S. Geological Survey, Middeton, Wisconsin, USA. [online] URL: http://wi.water.usgs.gov/pubs/WRIR-99-4083/ wrir-99-4083.pdf.

Foster, D., D. Kittredge, B. Donahue, G. Motzkin, D. Orwig, A. Ellison, B. Hall, B. Colburn, and A. D'Amato. 2005. Wildlands and woodlands: a vision for the forests of Massachusetts. Harvard Forest Paper 27. Harvard University, Petersham, Massachusetts, USA. [online] URL: http://harvardforest.fas.harvard.edu/sites/ harvardforest.fas.harvard.edu/files/publications/pdfs/HF_WandW. pdf.

Foster, D. R., G. Motzkin, and B. Slater. 1998. Land-use history as long-term broad-scale disturbance: regional forest dynamics in central New England. Ecosystems 1(1):96-119. http://dx.doi. org/10.1007/s100219900008

Fu, R., A. L. Thurman, T. Chu, M. M. Steen-Adams, and J. Zhu. 2013. On estimation and selection of autologistic regression models via penalized pseudolikelihood. Journal of Agricultural, Biological, and Ecological Statistics 18(3):429-449. http://dx.doi. org/10.1007/s13253-013-0144-Z

Garibaldi, A., and N. Turner. 2004. Cultural keystone species: implications for ecological conservation and restoration. Ecology and Society 9(3): 1. [online] URL: http://www.ecologyandsociety. org/vol9/iss3/art1/.

Geist, H. J., and E. F. Lambin. 2004. Dynamic causal patterns of desertification. BioScience 54(9):817-829. http://dx.doi. org/10.1641/0006-3568(2004)054[0817:DCPOD]2.0.CO;2

Godfrey, A. 1996. A forestry history of ten Wisconsin Indian reservations under the Great Lakes Agency. U.S. West Research, Inc., Salt Lake City, Utah, USA.

Goodale, C. L., and J. D. Aber. 2001. The long-term effects of land-use history on nitrogen cycling in northern hardwood forests. Ecological Applications 11(1):253-267. http://dx.doi.org/10.1890/1051-0761 (2001)011[0253:TLTEOL]2.0.CO:2

Gough, R. 1997. Farming the cutover: a social history of northern Wisconsin, 1900-1940. Kansas University Press, Lawrence, Kansas, USA.

Green, W. A. 1995. Periodizing world history. History and Theory 34(2):99-111. http://dx.doi.org/10.2307/2505437

Gunderson, L., and C. S. Holling. 2002. Panarchy: understanding transformations in human and natural systems. Island Press, Washington, D.C., USA.

Hagmann, R. K., J. F. Franklin, and K. N. Johnson. 2013. Historical structure and composition of ponderosa pine and mixed-conifer forests in south-central Oregon. Forest Ecology and Management 304:492-504. http://dx.doi.org/10.1016/j.foreco.2013.04.005

Hessburg, P. F., and J. K. Agee. 2003. An environmental narrative of the Inland Northwest United States forests, 1800-2000. Forest Ecology and Management 178(1-2):23-59. http://dx.doi. org/10.1016/S0378-1127(03)00052-5

Hirt, P. W. 1994. A conspiracy of optimism: management of the National Forests since World War Two. University of Nebraska Press, Omaha, Nebraska, USA.

Holzhueter, J. O. 1986. Madeline Island and the Chequamegon region. State Historical Society of Wisconsin Press, Madison, Wisconsin, USA.

Hughes, J. D. 2009. An environmental history of the World: humankind's changing role in the community of life. Second edition. Routledge, New York, New York, USA. 
Jin, C., J. Zhu, M. M. Steen-Adams, S. R. Sain, and R. E. Gangnon. 2013. Spatial multinomial regression models for nominal categorical data: a study of land cover in northern Wisconsin, USA. Envirometrics 24(2):98-108. http://dx.doi. org/10.1002/env.2189

Johnson, D. 2009. Manna in the form of jobs comes to the reservation. New York Times, February 21. [online] URL: http:// www.nytimes.com/1999/02/21/weekinreview/ideas-trends-mannain-the-form-of-jobs-comes-to-the-reservation.html.

Lambin, E. F., and H. J. Geist. 2003. Regional differences in tropical deforestation. Environment 45(6):22-36. http://dx.doi. org/10.1080/00139157.2003.10544695

Lambin, E. F., and P. Meyfroidt. 2010. Land use transitions: socio-ecological feedback versus socio-economic change. Land Use Policy 27(2):108-118. http://dx.doi.org/10.1016/j.

landusepol.2009.09.003

Lambin, E. F., B. L. Turner, H. J. Geist, S. B. Agbola, A. Angelsen, J. W. Bruce, O. T. Coomes, R. Dirzo, G. Fischer, C. Folke, P. S. George, K. Homewood, J. Imbemon, R. Leemans, X. Li, E. F. Moran, M. Mortimore, P. S. Ramakrishnan, J. F. Richards, H. Skånes, W. Steffen, G. D. Stone, U. Svedin, T. A. Veldkamp, C. Vogel, and J. Xu. 2001. The causes of land-use and land-cover change: moving beyond the myths. Global Environmental Change 11(4):261-269. http://dx.doi.org/10.1016/S0959-3780(01)00007-3

Langston, N. 1995. Forest dreams, forest nightmares: the paradox of old growth in the Inland West. University of Washington Press, Seattle, Washington, USA.

Langston, N. 2006. Restoration in the American national forests: ecological processes and cultural landscapes. Pages 173-183 in M. Agnoletti, editor. The conservation of cultural landscapes. CABI, Wallingford, UK. http://dx.doi.org/10.1079/9781845930745.0163

Lehmkuhl, J. F., P. F. Hessburg, R. L. Everett, M. H. Huff, and R. D. Ottmar. 1994. Historical and current forest landscapes of eastern Oregon and Washington. Part I: vegetation pattern and insect and disease hazards. General Technical Report PNWGTR-328. U.S. Department of Agriculture Forest Service, Pacific Northwest Research Station, Portland, Oregon, USA. [online] URL: http://www.fs.fed.us/pnw/publications/gtr328/pnw_gtr328a. pdf.

Liu, J., T. Dietz, S. R. Carpenter, M. Alberti, C. Folke, E. Moran, A. N. Pell, P. Deadman, T. Kratz, J. Lubchenco, E. Ostrom, Z. Ouyang, W. Provencher, C. L. Redman, S. H. Schneider, and W. W. Taylor. 2007a. Complexity of coupled human and natural systems. Science 317:1513-1516. http://dx.doi.org/10.1126/ science.1144004

Liu, J., T. Dietz, S. R. Carpenter, C. Folke, M. Alberti, C. L. Redman, S. H. Schneider, E. Ostrom, A. N. Pell, J. Lubchenco, W. W. Taylor, Z. Ouyang, P. Deadman, T. Kratz, and W. Provencher. 2007b. Coupled human and natural systems. Ambio 36(8):639-649. http://dx.doi.org/10.1579/0044-7447(2007)36[639: CHANS]2.0.CO;2

Loew, P. 1998. Newspapers and the Lake Superior Chippewa in the "unProgressive" era. Dissertation. University of WisconsinMadison, Madison, Wisconsin, USA.
Loew, P. 2013. Indian nations of Wisconsin: histories of endurance and renewal. Second edition. Wisconsin Historical Society Press, Madison, Wisconsin, USA.

Loomer, C. W. 1954 Land tenure problems in the Bad River Reservation of Wisconsin. Research Bulletin 188. University of Wisconsin Agricultural Experiment Station, Madison, Wisconsin, USA.

McNeill, J. R. 2000. Something new under the sun: an environmental history of the twentieth-century world. Norton, New York, New York, USA.

Millennium Ecosystem Assessment. 2005. Ecosystems and human well-being: synthesis. Island Press, Washington, D.C., USA. [online] URL: http://www.millenniumassessment.org/documents/ document.356.aspx.pdf.

Mladenoff, D. J., and J. Pastor. 1993. Sustainable forest ecosystems in the northern hardwood and conifer forest region: concepts and management. Pages 145-180 in G. H. Aplet, N. Johnson, J. T. Olson, and V. A. Sample, editors. Defining sustainable forestry. Island Press, Washington, D.C., USA.

Mladenoff, D. J., M. A. White, T. R. Crow, and J. Pastor. 1994. Applying principles of landscape design and management to integrate old-growth forest enhancement and commodity use. Conservation Biology 8(3):752-762. http://dx.doi.org/10.1046/ j.1523-1739.1994.08030752.x

Mladenoff, D. J., M. A. White, J. Pastor, and T. R. Crow. 1993. Comparing spatial pattern in unaltered old-growth and disturbed forested landscapes. Ecological Applications 3(2):294-306. http:// dx.doi.org/10.2307/1941832

Morrison, E. 2002. A little history of my forest life: an Indian-white autobiography. Reprint of 1894 edition. V. Brehm, editor. Ladyslipper Press, Tustin, Michigan, USA.

Motzkin, G., D. Foster, A. Allen, J. Harrod, and R. Boone. 1996. Controlling site to evaluate history: vegetation patterns on a New England sand plain. Ecological Monographs 66(3):345-365. http:// dx.doi.org/10.2307/2963522

Nayak, P. A. 2014. The Chilika Lagoon social-ecological system: an historical analysis. Ecology and Society 19(1): 1. http://dx.doi. org/10.5751/ES-05978-190101

Newell, A. S., R. L. Clow, and R. N. Ellis. 1986. A forest in trust: three-quarters of a century of Indian forestry 1910-1986. Historical Research Associates, Missoula, Montana, USA.

Newell, B., C. L. Crumley, N. Hassan, E. F. Lambin, C. PohlWostl, A. Underdal, R. Wasson. 2005. A conceptual template for integrative human-environment research. Global Environmental Change 15(5):299-307. http://dx.doi.org/10.1016/j.gloenvcha.2005.06.003

Newell, B., and R. Wasson. 2002. Social system vs solar system: why policy makers need history. Pages 3-17 in S. Castelein and A. Otte, editors. Conflict and cooperation related to international water resources: historical perspectives. UNESCO Document SC 2002/WS/53. UNESCO, Paris, France. [online] URL: http:// unesdoc.unesco.org/images/0012/001280/128073e.pdf.

Ostrom, E. 2005. Understanding institutional diversity. Princeton University Press, Princeton, New Jersey, USA. 
Ostrom, E., and H. Nagendra. 2006. Insights on linking forests, trees, and people from the air, on the ground, and in the laboratory. Proceedings of the National Academy of Sciences 103 (51):19224-19231. http://dx.doi.org/10.1073/pnas.0607962103

Parson, E. A. 2003. Protecting the ozone layer: science and strategy. Oxford University Press, Oxford, UK.

Pickett, S. T. A., M. L. Cadenasso, and J. M. Grove. 2005. Biocomplexity in coupled natural-human systems: a multidimensional framework. Ecosystems 8(3):225-232. http:// dx.doi.org/10.1007/s10021-004-0098-7

Pyne, S. J. 1982. Fire in America: a cultural history of wildland and rural fire. Princeton University Press, Princeton, New Jersey, USA.

Pyne, S. J. 2010. America's fires: a historical context for policy and practice. Forest History Society, Durham, North Carolina, USA.

Radeloff, V. C., D. J. Mladenoff, and M. S. Boyce. 2000. A historical perspective and future outlook on landscape scale restoration in the northwest Wisconsin pine barrens. Restoration Ecology 8(2):119-126. http://dx.doi.org/10.1046/j.1526-100x.2000.80018. $\underline{\mathrm{X}}$

Radeloff, V. C., D. J. Mladenoff, H. S. He, and M. S. Boyce. 1999. Forest landscape change in the northwest Wisconsin pine barrens from pre-European settlement and to the present. Canadian Journal of Forest Research 29(11):1649-1659. http://dx.doi. org/10.1139/x99-089

Rasmussen, C. O. 1998. Where the river is wide: Pahquahwong and the Chippewa flowage. Great Lakes Indian Fish and Wildlife Commission, Odanah, Wisconsin, USA.

Rasmussen, C. O. 2003. Ojibwe journies: treaties, Sandy Lake and the Waabanong Run. Great Lakes Indian Fish and Wildlife Commission, Odanah, Wisconsin, USA.

Ravenscroft, C., R. M. Scheller, D. J. Mladenoff, and M. A. White. 2010. Forest restoration in a mixed-ownership landscape under climate change. Ecological Applications 20(2):327-346. http://dx. doi.org/10.1890/08-1698.1

Rhemtulla, J. M., D. J. Mladenoff, and M. K. Clayton. 2007. Regional land-cover conversion in the U.S. upper Midwest: magnitude of change and limited recovery (1850-1935-1993). Landscape Ecology 22(S1):57-75. http://dx.doi.org/10.1007/ $\underline{\text { s10980-007-9117-3 }}$

Sandefur, G., M. Ceballos, and S. Mannon. 2000. Land and population on the Indian reservations of Wisconsin: past, present, and future. Working Paper 42. Land Tenure Center, University of Wisconsin-Madison, Madison, Wisconsin, USA. [online] URL: http://ageconsearch.umn.edu/bitstream/12780/1/ltcwp42.pdf.

Satz, R. N. 1991. The 1837 Pine Tree Treaty. Transactions of the Wisconsin Academy of Sciences, Arts, and Letters 79(1):13-31.

Schulte, L. A., and D. J. Mladenoff. 2005. Severe wind and fire regimes in northern forests: historical variability at the regional scale. Ecology 86(2):431-445. http://dx.doi.org/10.1890/03-4065

Spies, T. A., B. C. McComb, R. S. H. Kennedy, M. T. McGrath, K. Olsen, and R. J. Pabst. 2007. Potential effects of forest policies on terrestrial biodiversity in a multi-ownership province. Ecological Applications 17(1):48-65. http://dx.doi.org/10.1890/1051-0761 (2007)017[0048:PEOFPO]2.0.CO;2

Spotts, R. 1994. Preliminary analysis of conservation issues in the Kakagon/Bad River sloughs watershed. Wisconsin Chapter of the Nature Conservancy, Ashland, Wisconsin, USA.

Stearns, F. 1988. The changing forests of the lake states. Pages 25-35 in W. E. Shands, editor. The lake states forests: a resources renaissance. Lake States Forestry Alliance, Minneapolis, Minnesota, USA.

Steen-Adams, M. M. 2005. Change on a northern landscape: legacies of human history. Dissertation. University of Wisconsin, Madison, Wisconsin, USA.

Steen-Adams, M. M., N. Langston, and D. J. Mladenoff. 2007. White pine in the northern forests: an ecological and management history of white pine on the Bad River Reservation of Wisconsin. Environmental History 12(3):614-648. http://dx.doi.org/10.1093/ envhis/12.3.614

Steen-Adams, M. M., N. E. Langston, and D. J. Mladenoff. 2010. Logging the Great Lakes Indian reservations: the case of the Bad River Band of Ojibwe. American Indian Culture and Research Journal 34(1):41-66.

Steen-Adams, M. M., D. J. Mladenoff, N. E. Langston, F. Liu, and J. Zhu. 2011. Influence of biophysical factors and differences in Ojibwe reservation versus Euro-American social histories on forest landscape change in northern Wisconsin, USA. Landscape Ecology 26(8):1165-1178. http://dx.doi.org/10.1007/s10980-011-9630-2

Steffen, W., A. Sanderson, P. D. Tyson, J. Jäger, P. A. Matson, B. Moore III., F. Oldfield, K. Richardson, H. J. Schellnhuber, B. L. Turner II, and R. Wasson. 2004. Global change and the earth system: a planet under pressure. Springer-Verlag, Heidelburg, Germany.

Trout Unlimited-Wisconsin and Friends of White River. 2004. White River watershed management plan. Trout Unlimited Wild Rivers Chapter, Wisconsin, USA. [online] URL: https://dnrx. wisconsin.gov/swims/public/downloadDocument.do?id=22579928.

Troxell, P., M. Leach, J. Meeker, and K. Danielsen, editors. 2000. Northern forest restoration: shaping a vision. Proceedings of the Northern Forest Restoration - Shaping a Vision workshop. Sigurd Olson Institute, Northland College, Ashland, Wisconsin, USA.

Turner, M. G., D. N. Wear, and R. O. Flamm. 1996. Land ownership and land-cover change in the southern Appalachian Highlands and the Olympic Peninsula. Ecological Applications 6 (4):1150-1172. http://dx.doi.org/10.2307/2269599

Uekötter, F. 2010. The turning points of environmental history. University of Pittsburgh Press, Pittsburgh, Pennsylvania, USA.

U.S. Census Bureau. 1900-1990. Decennial census of population and housing. U.S. Census Bureau, Washington, D.C., USA. [online] URL: http://www.census.gov/prod/www/decennial.html.

U.S. Department of Agriculture. 1961. Soil survey reconnaissance: Bayfield County, Wisconsin. Series 1939, Number 30. U.S. Department of Agriculture Soil Conservation Service, U.S. 
Government Printing Office, Washington, D.C., USA. [online] URL: http://www.nrcs.usda.gov/Internet/FSE_MANUSCRIPTS/ wisconsin/bayfieldWI1961/bayfieldWI1961.pdf.

U.S. Department of the Interior. No date. A national cohesive wildland fire management strategy. U.S. Department of the Interior, Washington, D.C., USA. [online] URL: http://www. forestsandrangelands.gov/strategy/documents/reports/1 CohesiveStrategy03172011.pdf.

van Stappen, M. 1998. Northern passages: reflections from Lake Superior country. Prairie Oak Press, Madison, Wisconsin, USA.

Vogeler, I. 1983. Wisconsin. Westview Press, Boulder, Colorado, USA.

WDNR [Wisconsin Department of Natural Resources]. 1999. Ecological units of Wisconsin-first approximation, including Land Type Associations (LTAs). Wisconsin Department of Natural Resources, Madison, Wisconsin, USA.

WDNR [Wisconsin Department of Natural Resources]. 2007. Managing woodlands on Lake Superior's red clay plain: slowing the flow of runoff. Publication PUB-FR-385-2007. Wisconsin Department of Natural Resources, Madison, Wisconsin, USA. [online] URL: http://dnr.wi.gov/files/pdf/pubs/fr/FR0385.pdf.

WDNR [Wisconsin Department of Natural Resources]. 2012. Ecological landscapes of Wisconsin. Wisconsin Department of Natural Resources, Madison, Wisconsin, USA. [online] URL: http://nnr.wi.gov/topic/landscapes/.

White, R. 1991. The middle ground: Indians, Empires, and Republics in the Great Lakes region, 1650-1815. Cambridge University Press, Cambridge, UK.

White, M. A., and D. J. Mladenoff. 1994. Old-growth forest landscape transitions from pre-European settlemtn to present. Landscape Ecology 9(3):191-205. http://dx.doi.org/10.1007/ $\underline{\mathrm{BF} 00134747}$

Whitney, G. G. 1994. From coastal wilderness to fruited plain: a history of environmental change in temperate North America, 1500 to the present. Cambridge University Press, New York, New York, USA.

Williams, M. 1989. Americans and their forests: a historical geography. Cambridge University Press, Cambridge, UK.

Worster, D. 1988. Appendix: doing environmental history. Pages 289-308 in D. Worster, editor. The ends of the earth: perspectives on modern environmental history. Cambridge University Press, Cambridge, UK. http://dx.doi.org/10.1017/CBO9781139173599.014 